\title{
Changes to tropical eastern North Pacific intraseasonal variability under global warming, implications for tropical cyclogenesis
}

\author{
Hien X. BUI* and Eric D. MALONEY
}

Department of Atmospheric Science, Colorado State University, Fort Collins, CO, USA.

*Corresponding author; email: hien.bui@colostate.edu

Received: December 15, 2020; accepted: March 3, 2021

\begin{abstract}
RESUMEN
Los cambios en la Oscilación Intraestacional del Pacífico Tropical del Norte (ISO, por sus siglas en inglés) al final del siglo XXI y sus implicaciones para la génesis de los ciclones tropicales (CT) se analizan en el escenario Trayectorias Socioeconómicas Compartidas del conjunto de datos del Proyecto de Intercomparación de Modelos Acoplados fase 6 (CMIP6). Las medias combinadas multimodelo de vientos de nivel bajo y anomalías de precipitación asociadas con el modo dominante intraestacional muestran que la amplitud de la precipitación aumenta mientras que la del viento se debilita en un escenario de calentamiento global, de manera consistente con estudios previos sobre la alberca de agua caliente del Indo-Pacífico. El patrón intraestacional de precipitación y viento del Pacífico nororiental también tiende a desplazarse hacia el suroeste en un clima más cálido, asociado con anomalías positivas de precipitación más débiles cerca de la costa de México y Centroamérica durante la fase de intensificación de la convección y los vientos del oeste. Posteriormente se analizan las implicaciones del modo intraestacional dominante para la formación de CT mediante un índice potencial de formación (GPI, por sus siglas en inglés) de CT empírico. En la simulación histórica, el GPI muestra anomalías positivas en la fase de intensificación convectiva del ISO en la zona del Pacífico nororiental. La modulación del GPI por la ISO se debilita cerca de la costa de México y Centroamérica como resultado del calentamiento, en asociación con el desplazamiento hacia el sur de las anomalías del GPI. Un análisis más a fondo de la contribución de variables individuales que intervienen en el GPI muestra que la humedad relativa y los cambios de vorticidad que se manifiestan en los episodios del ISO debilitan con el calentamiento las anomalías positivas de este índice cerca de las costas mexicanas y favorecen la formación de CT hacia el suroeste. El impacto de los cambios anómalos de la cizalla vertical también favorece la formación lejos de la costa. Estos resultados sugieren una modulación más débil de los CT por el ISO cerca de la costa mexicana en un clima más cálido.
\end{abstract}

\begin{abstract}
Changes to the tropical eastern North Pacific Intraseasonal Oscillation (ISO) at the end of the 21st century and implications for tropical cyclone (TC) genesis are examined in the Shared Socioeconomic Pathways (SSP585) scenario of the Coupled Model Intercomparison Project phase 6 (CMIP6) data set. Multimodel mean composite low-level wind and precipitation anomalies associated with the leading intraseasonal mode indicate that precipitation amplitude increases while wind amplitude weakens under global warming, consistent with previous studies for the Indo-Pacific warm pool. The eastern North Pacific intraseasonal precipitation/wind pattern also tends to shift southwestward in a warmer climate, associated with weaker positive precipitation anomalies near the coast of Mexico and Central America during the enhanced convection/westerly wind phase. Implications for the modulation of TC genesis by the leading intraseasonal mode are then explored using an empirical genesis potential index (GPI). In the historical simulation, GPI shows positive anomalies in the eastern North Pacific in the convectively enhanced phase of the ISO. The ISO's modulation of GPI weakens near the coast of Mexico and Central America with warming, associated with a southward shift of
\end{abstract}


GPI anomalies. Further examination of the contribution from individual environmental variables that enter the GPI shows that relative humidity and vorticity changes during ISO events weaken positive GPI anomalies near the Mexican coast with warming and make genesis more favorable to the southwest. The impact of vertical shear anomaly changes is also to favor genesis away from the coast. These results suggest a weaker modulation of TCs near the Mexican Coast by the ISO in a warmer climate.

Keywords: ISO, global warming, eastern North Pacific, tropical cyclone.

\section{Introduction}

The eastern North Pacific (ENP) warm pool is a part of the Western Hemisphere warm pool (Wang and Enfield, 2001), approximately encompassed by the area east of $120^{\circ} \mathrm{W}$ and west of Mexico and Central America, where the surface temperature is generally above $27^{\circ} \mathrm{C}$. Although not as large as its Indo-Pacific counterpart, the ENP features similar large-scale atmospheric circulation, tropical convection, and tropical cyclone features and variability to that of the west Pacific warm pool (Misra et al., 2016). Tropical cyclones (TCs) that form in the ENP and their remnants are an important source of precipitation in Mexico and the southwestern United States (Englehart and Douglas, 2001; Ritchie et al., 2011; Domínguez and Magaña, 2018). On the intraseasonal time scale, the Madden Julian Oscillation (MJO; Madden and Julian, 1971, 1972; Maloney and Esbensen, 2003; Neena et al., 2014) modulates convection in this region during boreal summer, with notable northward propagation of convection anomalies (Jiang and Waliser, 2008, 2009; Maloney et al., 2008). Modeling evidence suggests that the ENP can support its own intraseasonal mode of variability (hereafter ENP ISO) in isolation from the Eastern Hemisphere, although variability in this region tends to phase-lock with the MJO (Jiang et al., 2012; Rydbeck et al., 2013). The ENP ISO has been implicated in the modulation of TC genesis and overall TC activity in this region (e.g., Molinari et al., 1997; Maloney and Hartmann, 2000, 2001; Higgins and Shi, 2005; Romero-Vadillo et al., 2007; Camargo et al., 2008; Klotzbach, 2010, 2014; Jiang et al., 2012; Slade and Maloney, 2013).

The MJO affects TC genesis by altering largescale environmental variables including relative vorticity, humidity, and vertical wind shear, with the relative importance of different variables depending on basin (Camargo et al., 2009; Zhao and Li, 2019). By analyzing a genesis potential index (GPI) using reanalysis data over the global oceans, Camargo et al. (2009) showed that midlevel relative humidity fluctuations make the largest contribution to MJO composite GPI anomalies, followed by contributions from low-level absolute vorticity, with only minor contributions from vertical wind shear and potential intensity. In the ENP region, while midlevel humidity and low-level vorticity are the two most important contributors to ISO composite GPI anomalies (Camargo et al., 2009), the relative importance of each variable depends strongly on location and ISO phase (Jiang et al., 2012). Previous studies have reported that TC development is increased (by up to four times) when lower-tropospheric wind anomalies in the east Pacific associated with the ISO are westerly (when convection is enhanced) vs. easterly (e.g., Maloney and Hartmann, 2000; Aiyyer and Molinari, 2008). Barotropic energy conversions from the mean state to eddies during the convective phase of the MJO have been hypothesized to contribute to the increase of cyclogenesis by strengthening the easterly wave seed disturbances for TCs (Maloney and Hartmann, 2001). Barrett and Leslie (2009) attributed increased TC formation during the ISO's convectively active phase to enhanced upper-tropospheric divergence. Given these impacts of the ISO on TC activity in the current climate, understanding changes of ENP intraseasonal variability under global warming and its influence on TC activity is of interest to people living in this region.

Much recent work has been conducted on MJO changes under global warming (see a review in Maloney et al., 2019). Global climate models generally predict that MJO precipitation amplitude will increase while MJO circulation strength increases at a slower rate or even weakens in the presence of global mean temperature warming (e.g., Takahashi et al., 2011; Arnold et al., 2013, 2015; Chang et al., 2015; Adames et al., 2017a, b; Bui and Maloney, 2018, 2019a, 2020; Rushley et al., 2019, among many others). Differences in the rate of change be- 
tween MJO precipitation and wind are explained by increased static stability in the tropics under global warming in the presence of weak horizontal temperature gradients (Bui and Maloney, 2019b). In addition, MJO variance is projected to shift further eastward into the central equatorial Pacific in a warmer climate (Bui and Maloney, 2018). Most of the studies above have focused on MJO change in the Eastern Hemisphere, with ISO change in the ENP receiving less emphasis. The fact that the ENP ISO tends to be poorly represented in most global climate models is likely one reason for this lack of emphasis (e.g., Jiang et al., 2013; Lin et al., 2008).

ISO variance and northward propagation in the ENP were underestimated in the previous climate models in phase 3 of the Coupled Model Intercomparison Project (CMIP3; Lin et al., 2008). The fifth phase of CMIP (CMIP5) shows some improvements in the ENP ISO, although only a few models can capture the spatial pattern of the leading mode of intraseasonal variability (Jiang et al., 2013). CMIP6 (Eyring et al., 2016) provides another state-of-theart multimodel dataset to advance our knowledge of climate variability and climate change. After documenting the ability of CMIP6 models to simulate ENP ISO precipitation and wind variability in current climate, we will examine how the ENP ISO changes at the end of the 21 st century in the Shared Socioeconomic Pathways (SSP) with fossil-fueled development combined with $8.5 \mathrm{~W} \mathrm{~m}^{-2}$ forcing scenario (SSP585; O'Neill et al., 2016) in 14 CMIP6 models. We will then use a GPI to infer how the modulation of TC genesis by the ENP ISO may change in a future warmer climate. The effect of anthropogenic forcing on the mean TC activity including its frequency, intensity, and spatial distribution has been extensively studied in recent years (see the review of Knutson et al., 2010, 2020; Murakami et al., 2020), although relatively little work has examined how the intraseasonal modulation of TC activity may change. In particular, we will quantify the contributions from changes in ENP ISO dynamics including wind shear and vorticity anomalies (e.g., Liebmann et al., 1994; Maloney and Hartmann, 2000; Hall et al., 2001) and relative humidity anomalies (e.g., Camargo et al., 2009) to changes in the ENP ISO's modulation of TC genesis in a future warmer climate.
We describe the CMIP6 models, observational datasets, and methodology in section 2. Section 3 examines projected ISO changes in the ENP at the end of the 21 st century in the SSP585 scenario, followed by an examination of the impacts on TC genesis in section 4 . The main conclusions are summarized in section 5 .

\section{Data and methodology}

\subsection{CMIP6 models and observational datasets}

The historical and the Shared Socioeconomic Pathways (SSP) with fossil-fueled development combined with $8.5 \mathrm{~W} \mathrm{~m}^{-2}$ forcing scenario (SSP585; O'Neill et al., 2016) experiments from 14 CMIP6 models (Eyring et al., 2016) were used to investigate changes of the ENP ISO and its impacts on TC genesis under anthropogenic warming. The present and future climate were defined using 1986-2005 in the historical run and 2081-2100 in SSP585, respectively. The 14 CMIP6 models examined provide daily mean data that are necessary for ISO-related diagnosis. A brief description and the spatial resolution of the models used are given in Table I.

Among these 14 models, 12 of them will be shown to produce a reasonable simulation of ENP intraseasonal variability in current climate, and only these models are used to examine changes of ENP ISO behavior with warming. These 12 models are indicated in bold in Table I. Due to the availability of variables that are needed to calculate TC potential intensity that goes into the calculation of genesis potential index (GPI), only eight of the 12 chosen models were included in the GPI calculation in section 4. These models are noted with an asterisk in Table I.

ENP ISO convective characteristics in the observed record are assessed using the Integrated Multi-satellitE Retrievals for Global Precipitation Measurement (GPM IMERG) version 6 (Huffman et al., 2018) and interpolated daily with outgoing longwave radiation (OLR) from the National Oceanic and Atmospheric Administration (NOAA) polar-orbiting satellite product (Liebmann and Smith, 1996). Observed ENP ISO wind variability is characterized using $850-\mathrm{hPa}$ zonal wind from the fifth global reanalysis produced by the European Center for Medium-Range Weather Forecasts (ERA5; Hersbach et al., 2020). All of the observational analysis covers the period 2001-2019. 
Table I. List of the 14 CMIP6 models used in this study. Models determined to have a good eastern North Pacific ISO in the current climate are noted in bold. Eight models included in the GPI calculation are noted with *

\begin{tabular}{|c|c|c|c|}
\hline \# & Model & Description & Resolution \\
\hline $1 *$ & BCC-CSM2-MR & Beijing Climate Center, China & $1.125 \times 1.125$ \\
\hline $\begin{array}{l}2^{*} \\
3^{*}\end{array}$ & $\begin{array}{l}\text { CESM2 } \\
\text { CESM2-WACCM }\end{array}$ & National Center for Atmospheric Research, USA & $1.25 \times 0.94$ \\
\hline $\begin{array}{l}4 \\
5\end{array}$ & $\begin{array}{l}\text { CNRM-CM6-1 } \\
\text { CNRM-CM6-1-HR }\end{array}$ & Centre National de Recherches Météorologiques, France & $\begin{array}{l}1.4 \times 1.4 \\
0.5 \times 0.5\end{array}$ \\
\hline $\begin{array}{l}6^{*} \\
7 \\
\end{array}$ & $\begin{array}{l}\text { EC-Earth3 } \\
\text { EC-Earth3-Veg }\end{array}$ & A European Community Earth System Model & $0.7 \times 0.7$ \\
\hline 8 & GFDL-CM4 & Geophysical Fluid Dynamics Laboratory, USA & $2.5 \times 2$ \\
\hline $9 *$ & MIROC6 & Model for Interdisciplinary Research on Climate, Japan & $1.4 \times 1.4$ \\
\hline $\begin{array}{l}10 \\
11 \\
\end{array}$ & $\begin{array}{l}\text { MPI-ESM1-2-HR } \\
\text { MPI-ESM1-2-LR }\end{array}$ & Max Planck Institute Earth System Model, Germany & $\begin{array}{c}0.94 \times 0.94 \\
1.875 \times 1.875\end{array}$ \\
\hline $12 *$ & MRI-ESM2 & Meteorological Research Institute, Japan & $1.125 \times 1.125$ \\
\hline $\begin{array}{l}13^{*} \\
14^{*}\end{array}$ & $\begin{array}{l}\text { NorESM2-LM } \\
\text { NorESM2-MM }\end{array}$ & Norwegian Climate Centre, Norway & $\begin{array}{l}2.5 \times 1.875 \\
1.25 \times 0.94\end{array}$ \\
\hline
\end{tabular}

Both model output and observational data are converted to a daily mean and have been interpolated to a common grid of $2.5^{\circ}$ (longitude) $2^{\circ}$ (latitude) before analysis. Only boreal summer (May to October) is examined in this study.

\subsection{ENP ISO composite and genesis potential index}

To highlight boreal summer intraseasonal variability in the ENP, a local ENP ISO index was generated from the first principal component (PC1) of the leading combined empirical orthogonal function (CEOF; e.g., Wheeler and Hendon, 2004; Lee et al., 2013) of 20-100 day filtered 850-hPa zonal wind and OLR over the ENP domain $\left(0^{\circ}-30^{\circ} \mathrm{N}, 75^{\circ}-125^{\circ} \mathrm{W}\right)$. Each field was normalized by its domain standard deviation before the CEOF analysis was conducted. The structure of this leading mode is shown in Figure 3, which explains 29.6 and $33.1 \%$ of the total variance in observations and historical simulation, respectively. The ENP ISO index created here is similar to that employed by Maloney and Hartmann (2001), except that a CEOF analysis is done rather than EOF analysis using only the $850-\mathrm{hPa}$ zonal wind field. Maloney et al. (2008) and Jiang et al. (2013) similarly produced a local ENP intraseasonal index based on the leading complex EOF of 30-90 day filtered precipitation. In our analysis, days when the PC time series of the leading CEOF is greater than $1 \sigma$ are used for composite analysis, corresponding to positive precipitation anomalies and anomalous low-level westerly winds. Composites based on negative deviations of the index have a similar pattern, but with opposite sign (see Fig. S1 in the supplementary materials).

We use the TC genesis potential index (GPI) developed by Emanuel and Nolan (2004) and discussed in detail by Camargo et al. (2007) to assess how ENP ISO changes affect TC genesis potential in a warmer climate. Following Camargo et al. (2009), the GPI is calculated as

GPI $=\left|10^{5} \eta\right|^{3 / 2}\left(\frac{\mathcal{H}}{50}\right)^{3}\left(\frac{\mathrm{PI}}{70}\right)^{3}\left(1+0.1 V_{\text {shear }}\right)^{-2}$

where $\eta$ is the absolute vorticity at $850 \mathrm{hPa}\left(\mathrm{s}^{-1}\right)$, $\mathcal{H}$ is the relative humidity at $600 \mathrm{hPa}(\%), \mathrm{PI}$ is the potential intensity $\left(\mathrm{m} \mathrm{s}^{-1}\right)$, and $V_{\text {shear }}$ is the magnitude of the vertical wind shear between 850 and $250 \mathrm{hPa}$ $\left(\mathrm{m} \mathrm{s}^{-1}\right)$. The potential intensity (PI) is calculated based on Emanuel (1995) as modified by Bister and Emanuel (1998). Since daily values at sufficient vertical resolution are not available for most models 
to adequately calculate PI, we use monthly mean surface temperature and pressure and vertical profiles of atmospheric temperature and humidity. While this prevents a realistic depiction of intraseasonal PI variations, PI has been shown to only produce minor contribution to intraseasonal TC genesis potential variations in the east Pacific (Camargo et al., 2009). To assess the individual importance of the variables that comprise the GPI for determining the ENP ISO GPI anomalies, the following method is used. First, the GPI is calculated where all three variables other than PI (i.e., $\left.\eta, \mathcal{H}, V_{\text {shear }}\right)$ are allowed to fully vary. Then, we recompute the GPI such that two out of the three variables are allowed to vary, but with the climatological annual cycle of the remaining variable input. This quantity can then be subtracted from the GPI calculated using all variables to assess the importance of the variable of interest. This allows more nonlinearity in the calculation than setting all variables to the climatological mean as done in Camargo et al. (2009). The method therefore provides a better quantitative estimate of the relative importance of the different factors to intraseasonal variability of GPI anomalies.

\section{Changes in the ENP ISO}

\subsection{Changes in summer mean state}

We first briefly discuss the multimodel mean oceanic climatological May-October precipitation, $850 \mathrm{hPa}$ zonal wind and OLR distributions over the eastern North Pacific (Fig. 1). Given our emphasis on warm pool intraseasonal variability and TC genesis potential, we only concentrate on oceanic fields in this analysis. Similar plots from satellite and reanalysis fields can be found in Maloney and Esbensen (2007) and Xie et al. (2005), and from CMIP5 models in Jiang et al. (2013). The multimodel mean precipitation in the historical CMIP6 simulation has the main axis of the ITCZ centered at around $9^{\circ} \mathrm{N}$ (Fig. 1a), coincident with the minimum OLR in the ITCZ region (Fig. 1c), which expands northward toward the coast east of $120^{\circ} \mathrm{W}$. We note that the precipitation minimum over the cold waters west of Costa Rica Dome $\left(9^{\circ} \mathrm{N}\right.$ and $90^{\circ} \mathrm{W}$; also see figure 4 in Xie et al., 2005 ) is still not well-produced in the CMIP6 models analyzed here. The $850 \mathrm{hPa}$ zonal wind is dominated by an easterly component (Fig. 1e), although the flow at the surface is mean westerly near $10^{\circ} \mathrm{N}$ in the ENP warm pool (not shown here). This basic state flow has implication for air-sea interaction, since a westerly anomaly at the surface would produce enhanced wind speed and surface latent heat flux (Maloney and Esbensen, 2003) that has been argued to be important for the dynamics of ISO in the ENP (e.g., Maloney and Esbensen, 2007; Maloney et al., 2008).

Under global warming, mean precipitation increases over the southern part of the ENP between $5^{\circ}$ to $10^{\circ} \mathrm{N}$ and west of $150^{\circ} \mathrm{W}$ (Fig. 1b), suggesting a strengthening and southwestward shift of mean precipitation within the ENP intertropical convergence zone (ITCZ). The westward shift may be related to a more frequent occurrence of central Pacific El Niño in a future warmer climate (see Fig. S2 in the supplementary materials for the entire tropical pattern; Yeh et al., 2009). This feature is also clearly apparent in the OLR pattern (Fig. 1d). These projected changes in the mean state convection are also in agreement with previous results from the CMIP3 (Neelin et al., 2006) and CMIP5 (Jiang et al., 2013) datasets, and other models (Maloney et al., 2014). In general, the pattern resembles the "rich-get-richer" pattern of precipitation change found in previous warming studies (e.g., Chou et al., 2009). It is also worth noting that precipitation near the Mexico coast, where most tropical cyclones occur in current climate, tends to slightly decrease, consistent with previous findings of Jiang et al. (2013). Implications for future changes of tropical cyclogenesis in this region will be further discussed below.

\subsection{Changes in the ISO amplitude over the ENP}

We now analyze precipitation and wind anomalies over the ENP warm pool on intraseasonal timescales. Figure 2 shows the multimodel mean amplitude of intraseasonal variability (calculated as 20-100-day filtered variance fields) from the historical simulation and differences between SSP585 and the historical simulation. In the historical simulation, intraseasonal precipitation generally maximizes in regions of high mean precipitation, although the maximum is slightly shifted toward the coast relative to the mean precipitation pattern (Fig. 2a). The $850 \mathrm{hPa}$ zonal wind variance peak occurs just south of the precipitation variance peak. The ENP ISO OLR variance peak (Fig. 2c) occurs to the west of the ISO precipitation 
(a) Precipitation (Hist)
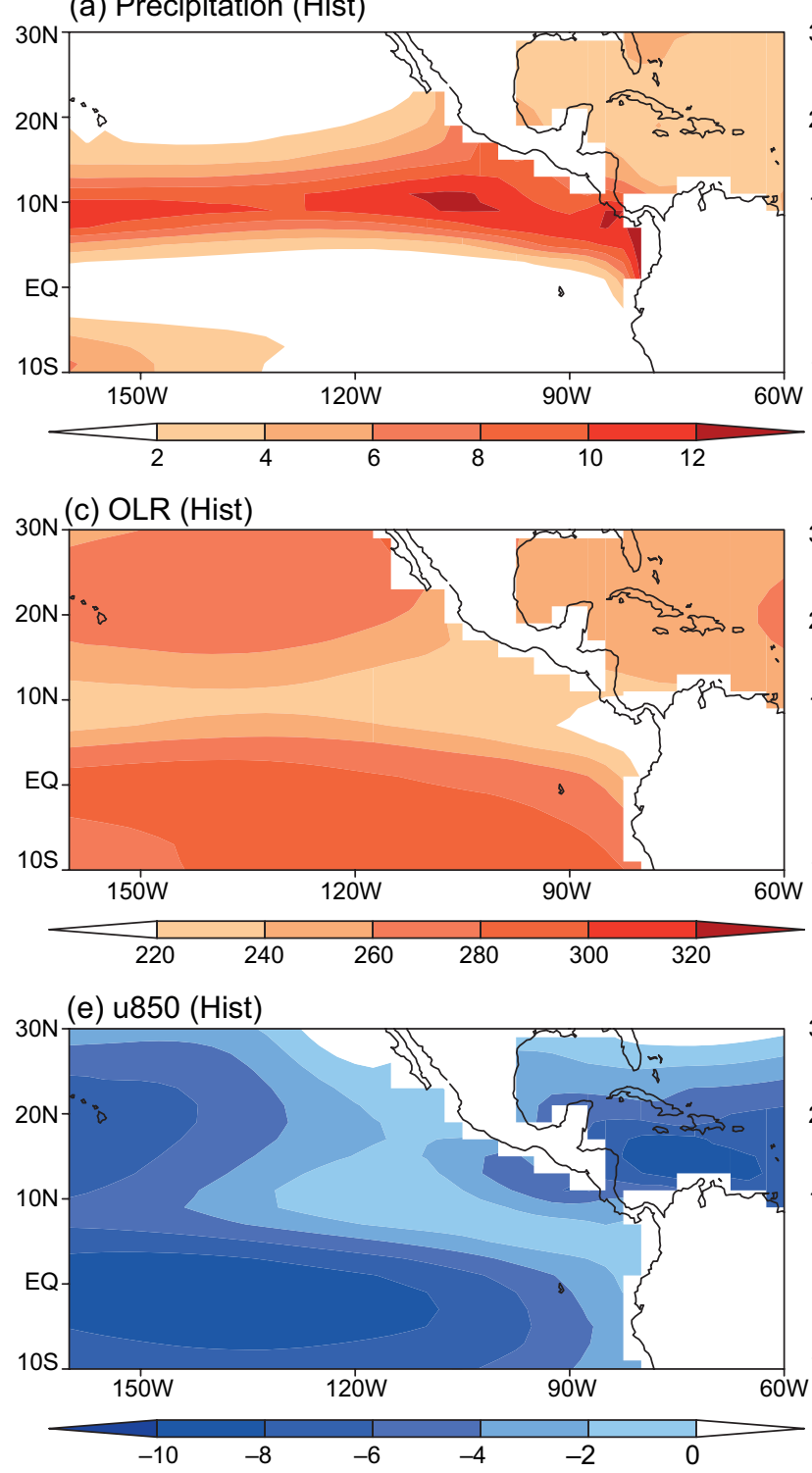

(b) Precipitation (SSP585-Hist)

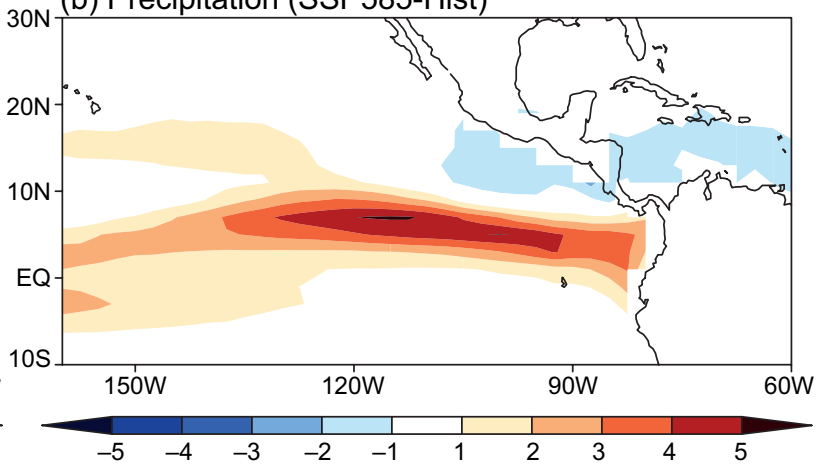

(d) OLR(SSP585-Hist)
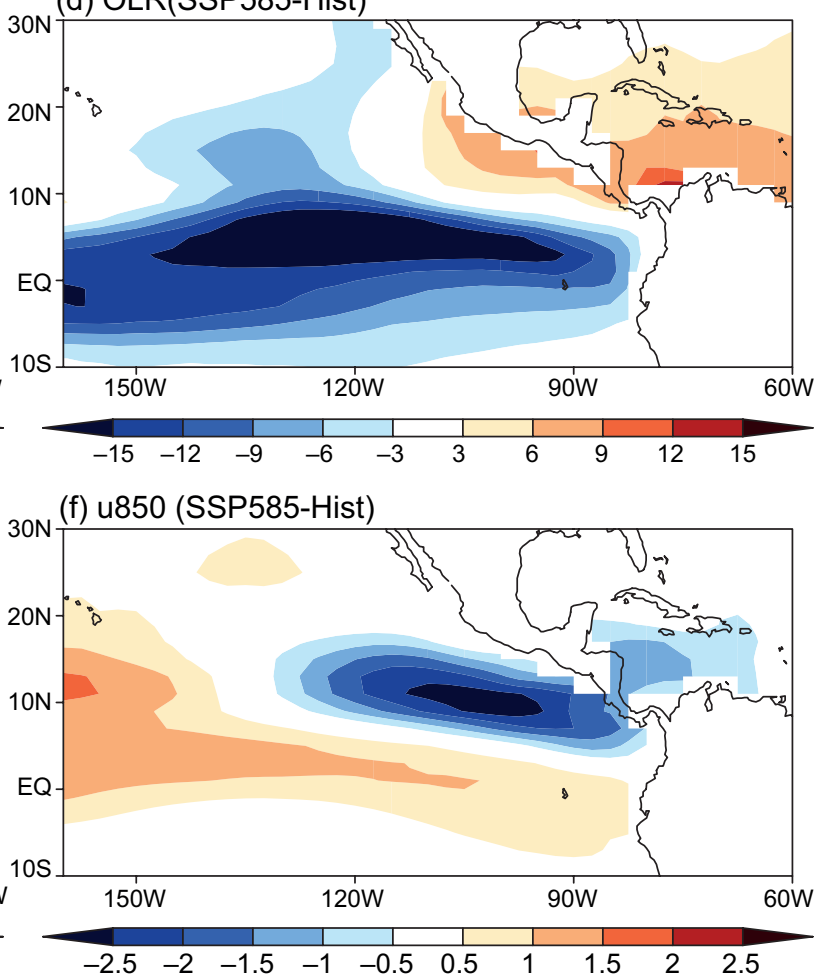

Fig. 1. Multimodel mean (from 14 CMIP6 models) spatial distribution of the boreal summer climatological mean. (a, b) Precipitation $\left(\mathrm{mm} \mathrm{day}^{-1}\right),(\mathrm{c}, \mathrm{d})$ outgoing longwave radiation (OLR; $\left.\mathrm{W} \mathrm{m}^{-2}\right)$, and (e, f) $850 \mathrm{hPa}$ zonal wind $\left(\mathrm{m} \mathrm{s}^{-1}\right.$ ) for the historical simulation and differences between SSP585 and historical simulations, respectively. See Figure S2 in the supplementary material for the entire tropical pattern.

and $850 \mathrm{hPa}$ zonal wind variance maxima (Fig. 2e). The multimodel mean intraseasonal variability fields are generally consistent with those in observations (Maloney and Esbensen, 2003) and CMIP5 models (Jiang et al., 2013). Examination of individual models, including the model spread and the magnitude of variability compared to observations, is presented in Figure 4.
Figure $2 b, d$ and $f$ shows the differences in multimodel mean intraseasonal variance between 20812100 and 1986-2005. Largely mimicking the mean precipitation changes shown in Figure 1, an increase in precipitation variance occurs between $5^{\circ}$ and $10^{\circ} \mathrm{N}$, and with a modest decrease in variance near a portion of the ENP Mexican coast. The southwestward shift of ENP ISO precipitation variance is also clearly seen in 
(a) Precipitation (Hist)

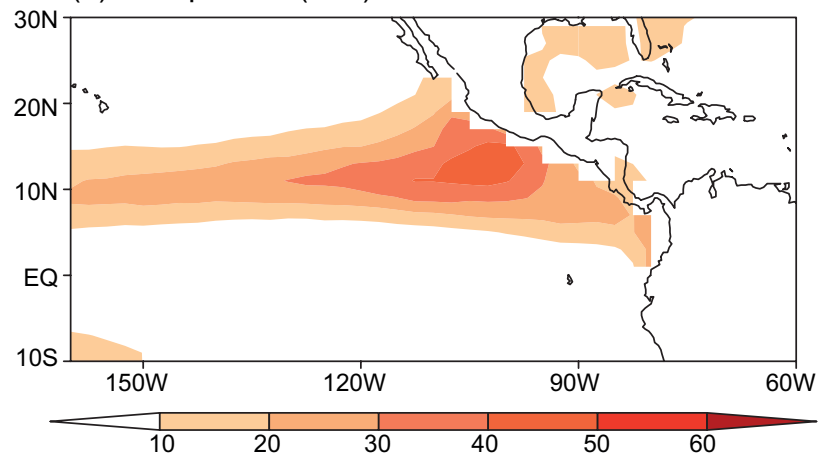

(c) OLR (Hist)

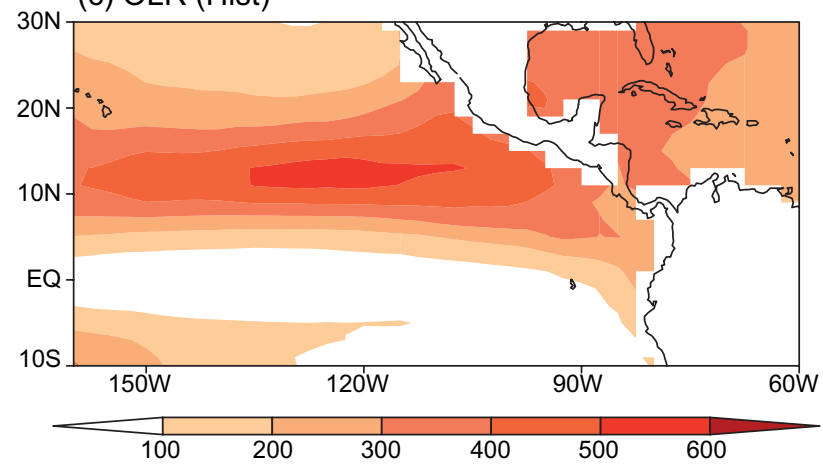

(e) $u 850$ (Hist)

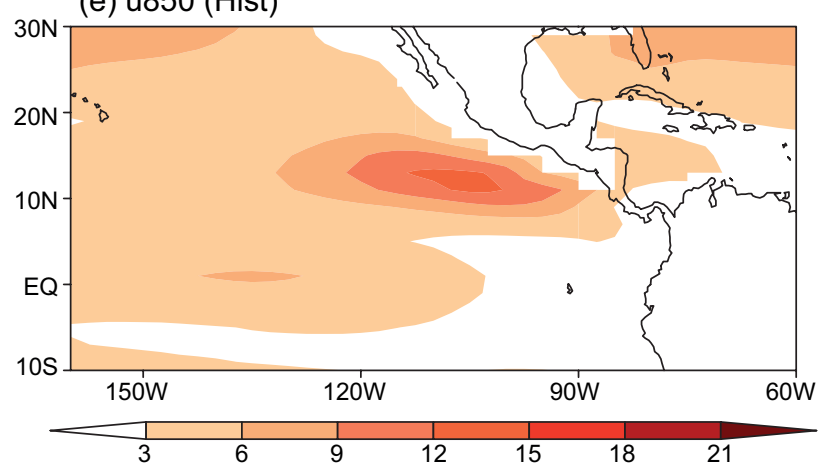

(b) Precipitation (SSP585-Hist)

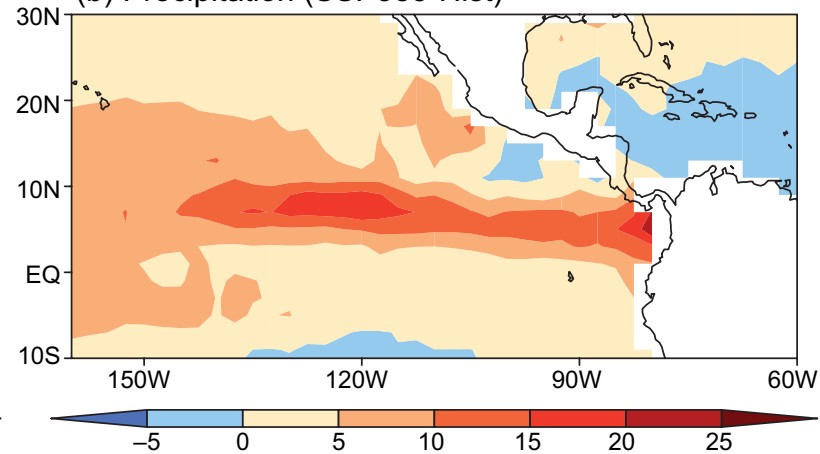

(d) OLR(SSP585-Hist)
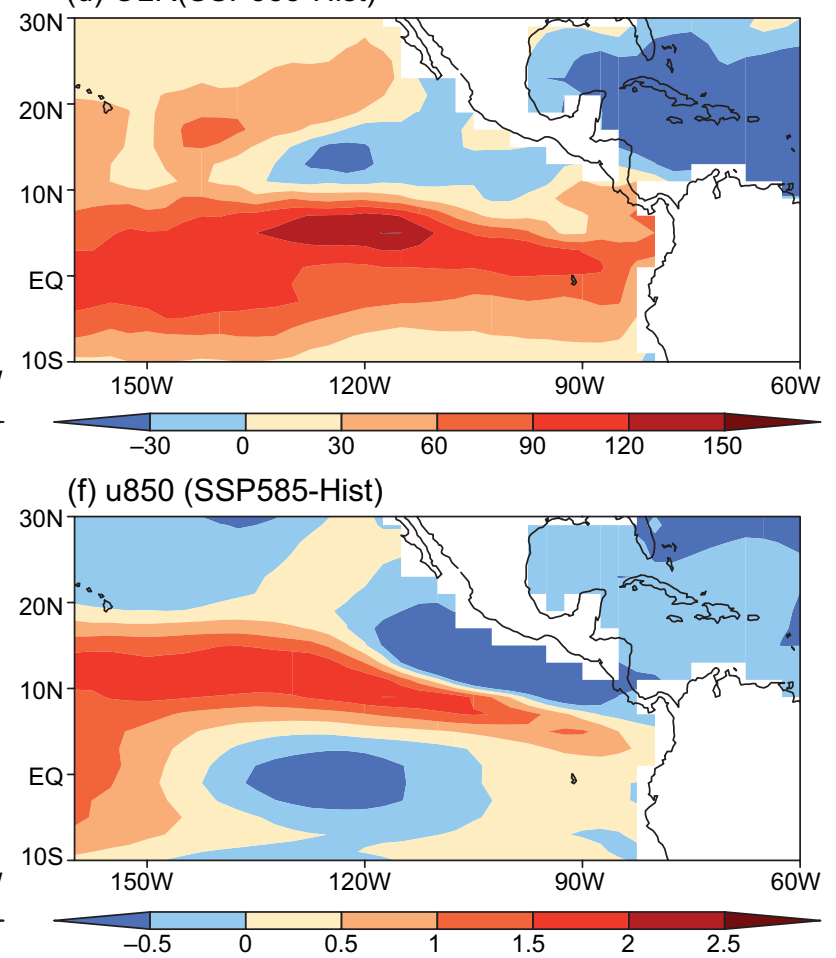

Fig. 2. Multimodel mean (from 14 CMIP6 models) spatial distribution of the boreal summer 20-100 day filtered. (a, b) precipitation $\left(\mathrm{mm}^{2}\right.$ day $\left.^{-2}\right),(\mathrm{c}, \mathrm{d})$ outgoing longwave radiation $\left(\mathrm{OLR} ; \mathrm{W}^{2} \mathrm{~m}^{-2}\right)$, and (e, f) $850 \mathrm{hPa}$ zonal wind $\left(\mathrm{m}^{2}\right.$ $\mathrm{s}^{-2}$ ) variance for the historical simulation and differences between SSP585 and historical simulations, respectively. See Figure S3 in the supplementary material for the entire tropical pattern.

the OLR (Fig. 2d), where an opposite signed change of OLR variance occurs near the Mexican coast relative to that south of $10^{\circ} \mathrm{N}$. A similar shift is also seen in the $850 \mathrm{hPa}$ zonal wind variance field (Fig. 2f). While coastal precipitation variance changes are modest, reductions in the amplitude of wind variability are of greater amplitude. The relative weakening of intraseasonal wind variability relative to precipitation variability is consistent with that shown in previous studies for the MJO, which can be explained by increasing static stability of the tropical troposphere under climate warming (Maloney et al., 2019; see also Fig. S4). Interestingly, similar increases of MJO precipitation variance and weakening of $\mathrm{MJO}$ wind variance under global warming also occur over the Indian monsoon/Bay of Bengal region (see Fig. S3 in the supplementary material). 
In order to identify the leading intraseasonal modes over the ENP in both observations and CMIP6 simulations, a CEOF analysis is conducted using the $850 \mathrm{hPa}$ zonal wind and OLR. Spatial patterns of the leading CEOF from observations and the multimodel mean of the leading CEOF from individual models are shown in Figure 3 (see Fig. S4 for the pattern of the second CEOF), with the variance explained listed in the caption and on top of each figure. OLR amplitude in CEOF1 peaks between $10^{\circ}-20^{\circ} \mathrm{N}$ in observations, with an $850 \mathrm{hPa}$ zonal wind peak on its south flank, is consistent with Maloney and Esbensen $(2003,2005,2007)$. The variability in this region also coincides with the ENP hurricane genesis region (see figure 1 in Maloney and Hartmann, 2000). While CMIP6 shows a similar pattern as observed, we note that the historical simulations tend to have higher variance that extends further to the west than observations. The leading EOF in SSP585 becomes slightly more diffuse and the peak amplitudes shift westward (cf. Fig. 3b, c), behavior that is possibly seen better in the difference plot (Fig. 3d, h). The amplitude of zonal wind and OLR in the leading EOF both decrease near the coast in SSP585 relative to the historical simulations. The explained variance of CEOF1 is also decreased in SSP585 relative to the historical period (e.g., 25.6 vs. 33.1\%).

Motivated by Jiang et al. (2013), the fidelity in simulating the leading ENP ISO mode by each CMIP6 model is then objectively assessed by calculating the pattern correlation of the simulated CEOF1 against its observed counterpart. Pattern correlations between observed and simulated CEOF1 patterns over the ENP domain are calculated individually for $850 \mathrm{hPa}$ zonal wind and OLR, and then a final pattern correlation score for a particular model is derived by averaging these two correlation coefficients. We also calculate the relative amplitude of models' precipita-
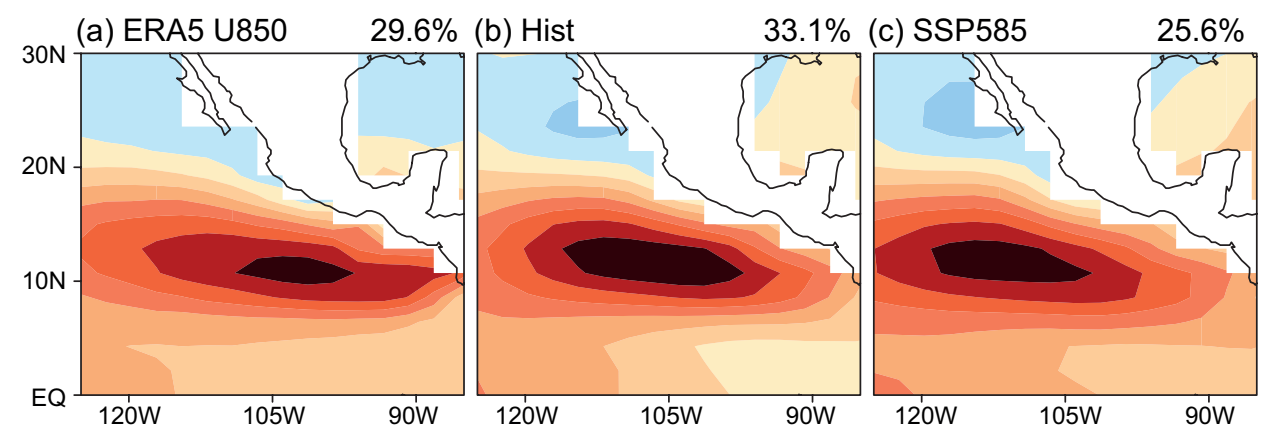

(d) SSP585-Hist

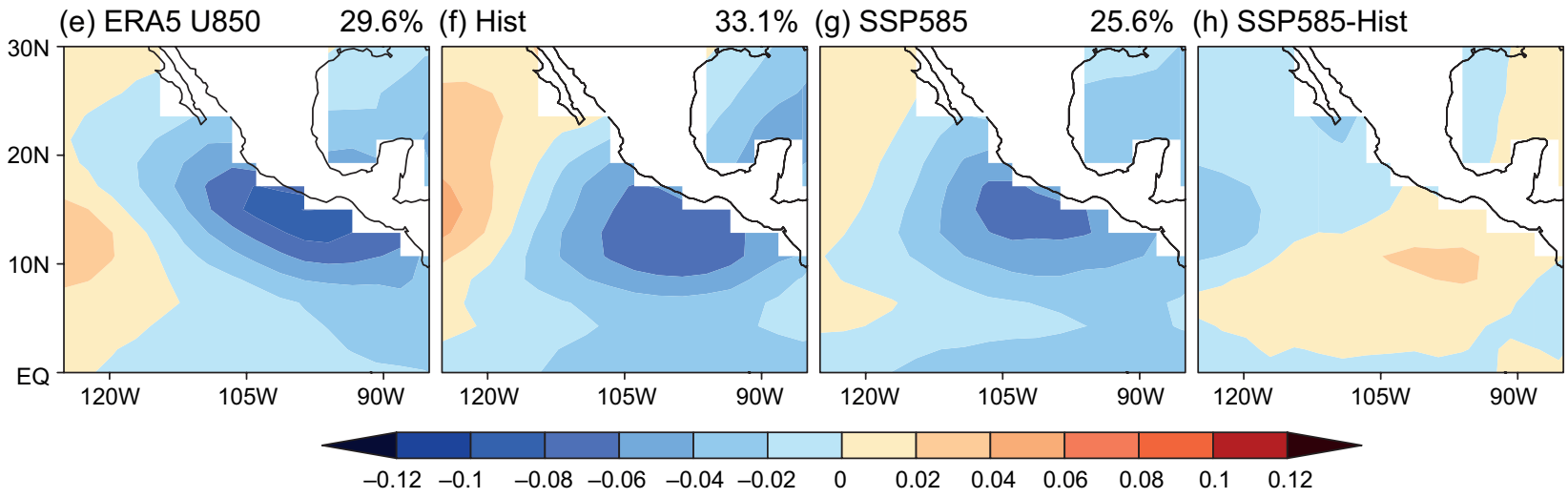

Fig. 3. Spatial distribution of the leading CEOF mode of $850 \mathrm{hPa}$ zonal wind and outgoing longwave radiation (OLR) during boreal summer over the eastern north Pacific for (a, e) observations (explain $29.6 \%$ of the total variance), (b, f) mulimodel mean of the CMIP6 historical simulations (33.1\% of total variance), (c, g) multimodel mean of the SSP585 simulations (25.6\% of total variance), and $(\mathrm{d}, \mathrm{h})$ differences between SSP585 and historical simulations. See Figure S4 in the supplementary material for the spatial pattern of the second leading CEOF. 
tion and wind to observations by computing the root mean square of the composite precipitation and 850 hPa zonal wind (shown in Fig. 5) over the domain of $10^{\circ}-20^{\circ} \mathrm{N}, 95^{\circ}-115^{\circ} \mathrm{W}$. As shown in Figure 4, while most of the CMIP6 models produce a reasonable pattern correlation $(>0.8)$ relative to observations ( $x$-axis), biases in the relative amplitude of ISO precipitation and wind ( $y$-axis) are apparent, associated with overestimation of the amplitude of the ENP ISO $850 \mathrm{hPa}$ zonal wind and underestimation of the amplitude of precipitation variability. The two models that have relatively low pattern correlations of 0.7 or less, i.e., MPI-ESM-2-HR and MPI-ESM-2-LR, are excluded from further analyses.

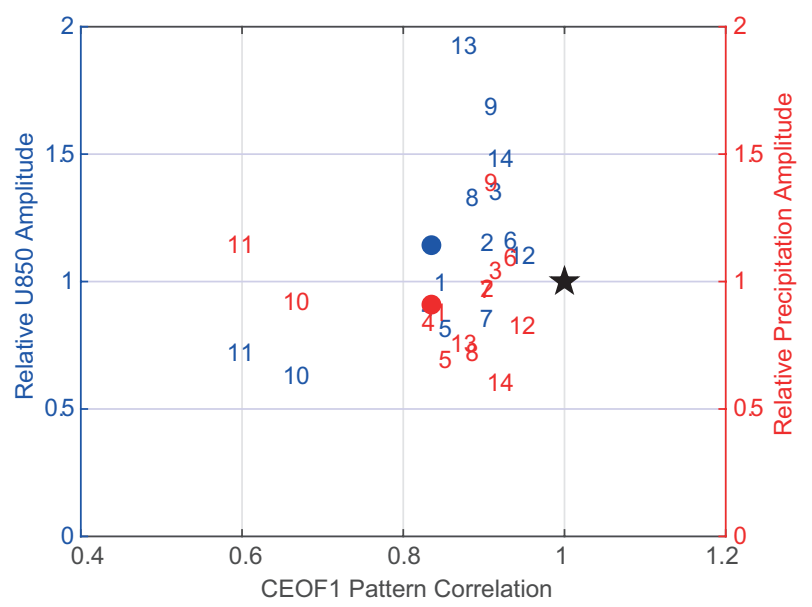

Fig. 4. The $x$-axis shows pattern correlation coefficients of CEOF1 between observations and CMIP6 historical simulations. The $y$-axes show relative composite amplitude of $850 \mathrm{hPa}$ zonal wind (blue, left axis) and precipitation (red, right axis) of the models to observations averaged over the domain of $10^{\circ}-20^{\circ} \mathrm{N}, 95^{\circ}-115^{\circ} \mathrm{W}$. The black star represents the observations and the circles represent the CMIP6 multimodel mean. The 14 CMIP6 models are indexed according to Table I.

Multimodel mean composite patterns of the remaining CMIP6 models' precipitation, OLR and 850 $\mathrm{hPa}$ vector winds anomalies derived using days $>1 \sigma$ in the time series of CEOF1, with a similar analysis for observations, are shown in Figure 5. Positive deviations of the index correspond to the enhanced intraseasonal convective phase in this region. In general, the CMIP6 multimodel mean shows a similar composite pattern to observations, with maximum precipitation occurring near the coast from $10^{\circ}-20^{\circ}$ $\mathrm{N}$, except with smaller amplitude. As in observations, stronger ISO precipitation tends to be associated with westerly wind and negative OLR anomalies. Under global warming, the maximum precipitation anomaly tends to shift to the west, weakening the positive anomaly near the coastal region (Fig. 5c). Westerly wind anomalies also weaken with warming. The westward shift in the pattern of convection is also clearly seen in the OLR composites (Fig. 5f).

We also examine changes in composite ISO precipitation and wind anomalies for each model averaged over the same domain $\left(10^{\circ}-20^{\circ} \mathrm{N}, 95^{\circ}-115^{\circ} \mathrm{W}\right)$ as shown in Figure 5. In Figure 6, 10 out of 12 models show a weakening in the $850 \mathrm{hPa}$ zonal wind anomalies in a warmer climate relative to present, with a multimodel mean decrease of about $-4.7 \% \mathrm{~K}^{-1}$. ISO precipitation increase in most of the models $\left(\sim 1.9 \% \mathrm{~K}^{-1}\right.$ in the multimodel mean), associated with the westward shift in the precipitation anomaly pattern. Note that we define the ENP ISO amplitude by computing the root mean square of the composited fields in Figure 5, and all the values have been normalized by the historical simulation and are expressed per unit global mean surface temperature warming. Results are also similar when using the standard deviation calculated from filtered fields to define the amplitude, rather than a composite analysis (not shown). Consistent with our previous studies for the global MJO (Bui and Maloney, 2018, 2019a), while ISO precipitation amplitude increases in most models with warming, wind amplitude increases at a slower rate or decreases with warming. This relationship is expected from an increase in tropical static stability with warming (Fig. S5 in the supplementary material; also see Bui and Maloney, 2019b).

\section{Implications for TC genesis}

To draw connections between ISO amplitude and structure changes and implications for the modulation of TC genesis in the ENP in a warmer climate, Figure 7 shows a composite for the three most important environmental variables to the intraseasonal modulation of TC genesis according to Camargo et al. (2009): mid-level relative humidity, low-level relative vorticity, and magnitude of vertical wind shear. Figure $7 \mathrm{a}-\mathrm{c}$ 
(a) GPM precipitation

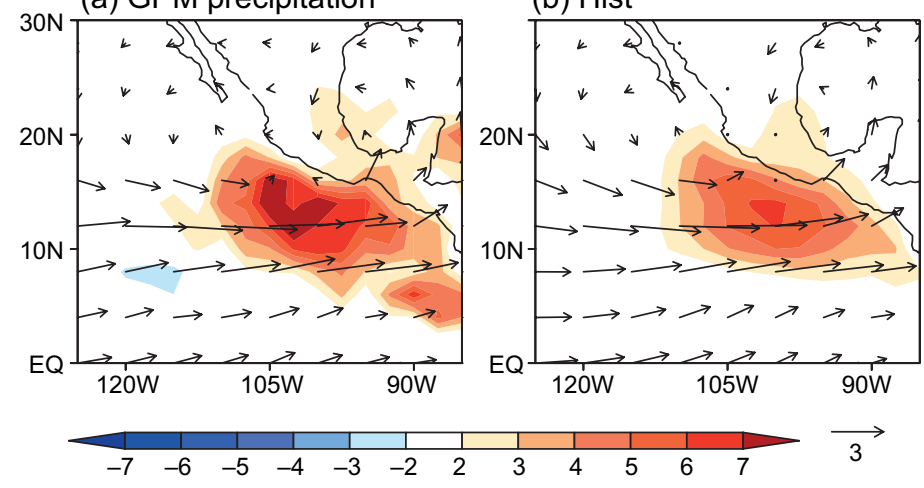

(d) NOAA OLR

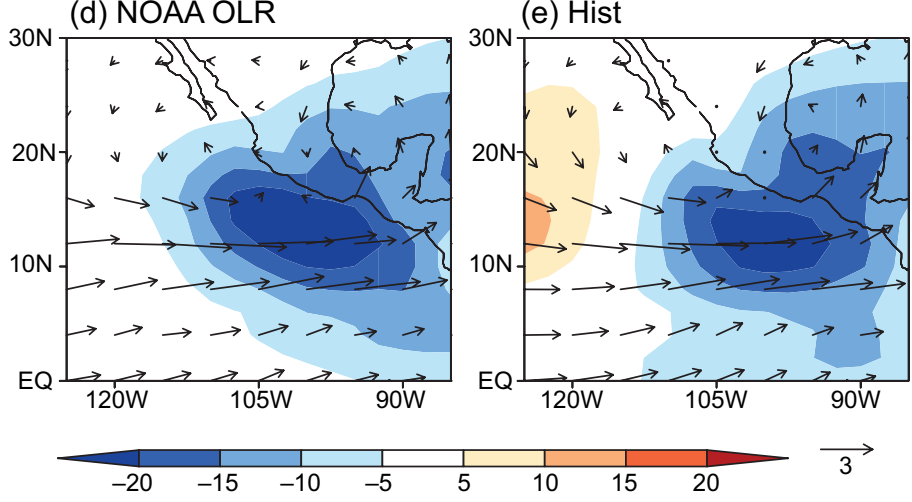

(c) SSP585-Hist
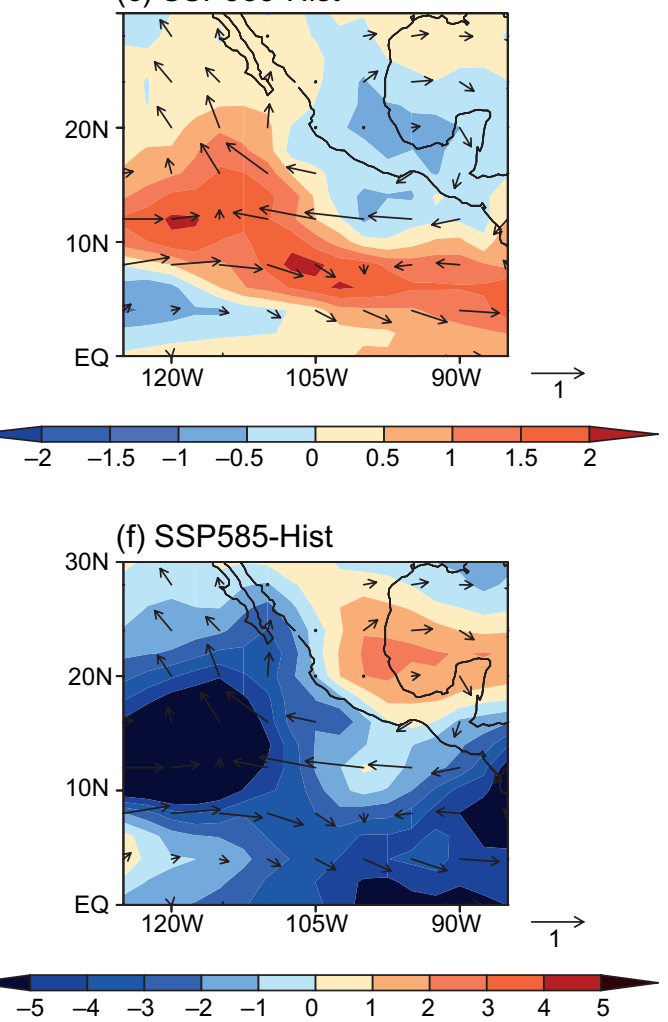

Fig. 5. Boreal summer 20-100 day filtered (a-c) precipitation (shaded, $\mathrm{mm} \mathrm{day}^{-1}$ ), (d-f) OLR (shaded, $\mathrm{W} \mathrm{m}^{-2}$ ) and 850 $\mathrm{hPa}$ wind vector $\left(\mathrm{m} \mathrm{s}^{-1}\right)$ composites based on the PC1 timeseries from (a, d) observations, (b, e) historical simulation and (c, f) differences between SSP585 and historical simulations. See Figure S1 in the supplementary material for the composites based on negative deviations of the PC1 timeseries.

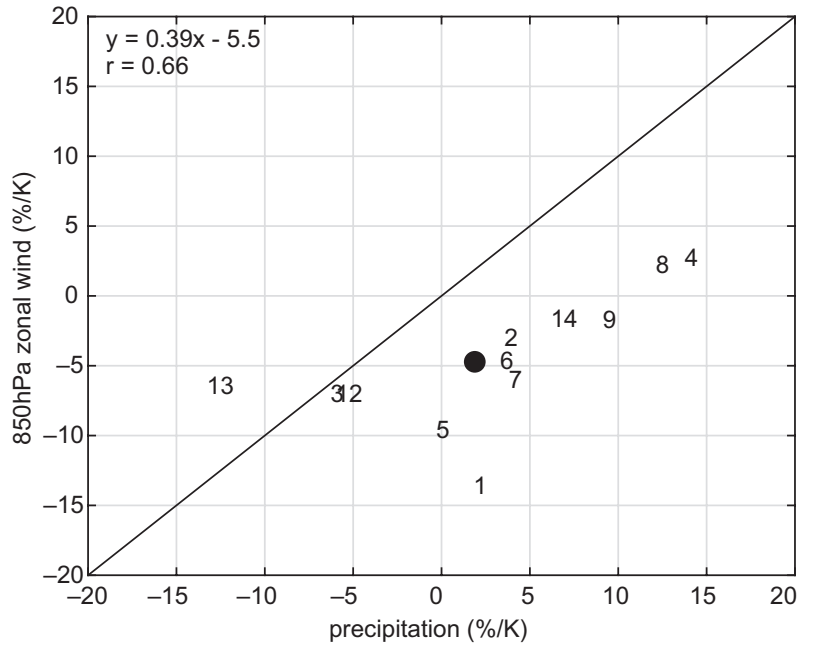

Fig. 6. Scatterplot of ENP ISO $850 \mathrm{hPa}$ zonal wind amplitude ( $y$-axis) and precipitation amplitude ( $x$-axis) changes at the end of 21 st century relative to historical simulation from 12 selected CMIP6 models averaged over the domain of $10^{\circ}-20^{\circ} \mathrm{N}, 95^{\circ}-115^{\circ} \mathrm{W}$. All values have been normalized by the historical simulation and are expressed per unit global mean surface temperature warming $\left(\% \mathrm{~K}^{-1}\right)$. The 12 selected CMIP6 models are indexed according to Table I. The black circle represents the multimodel mean. 
(a) ERA5 RH600

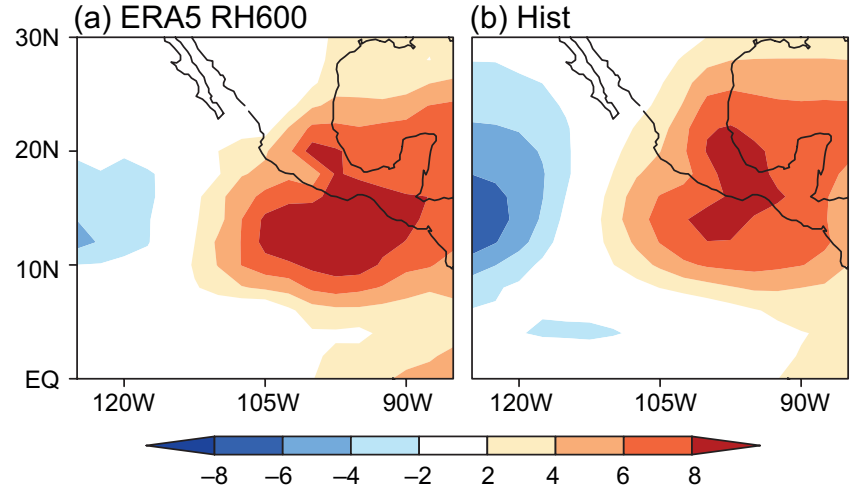

$30 \mathrm{~N}$ (d) ERA5 Vorticity

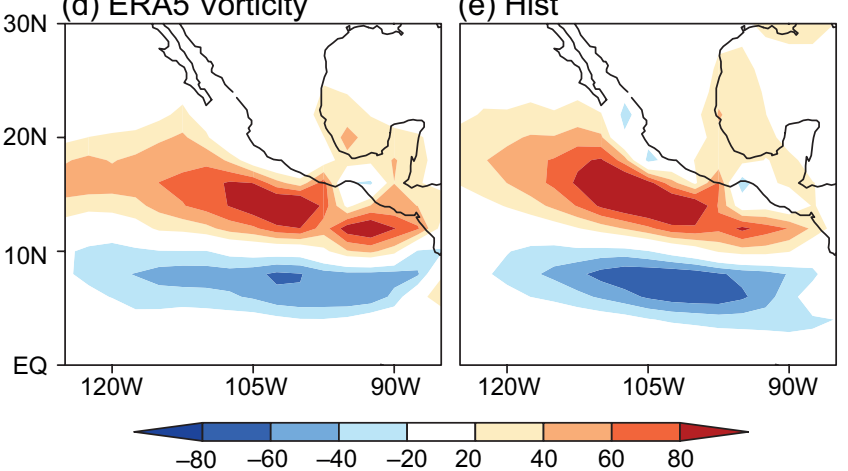

(g) ERA5 Shear

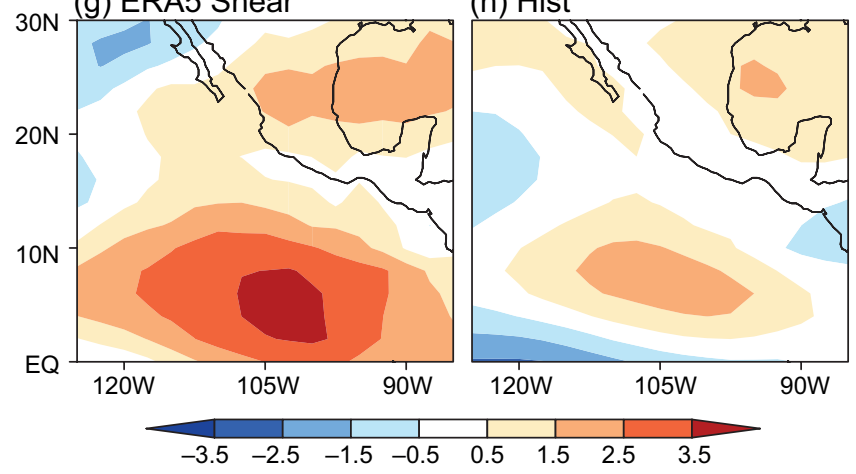

(c) SSP585-Hist
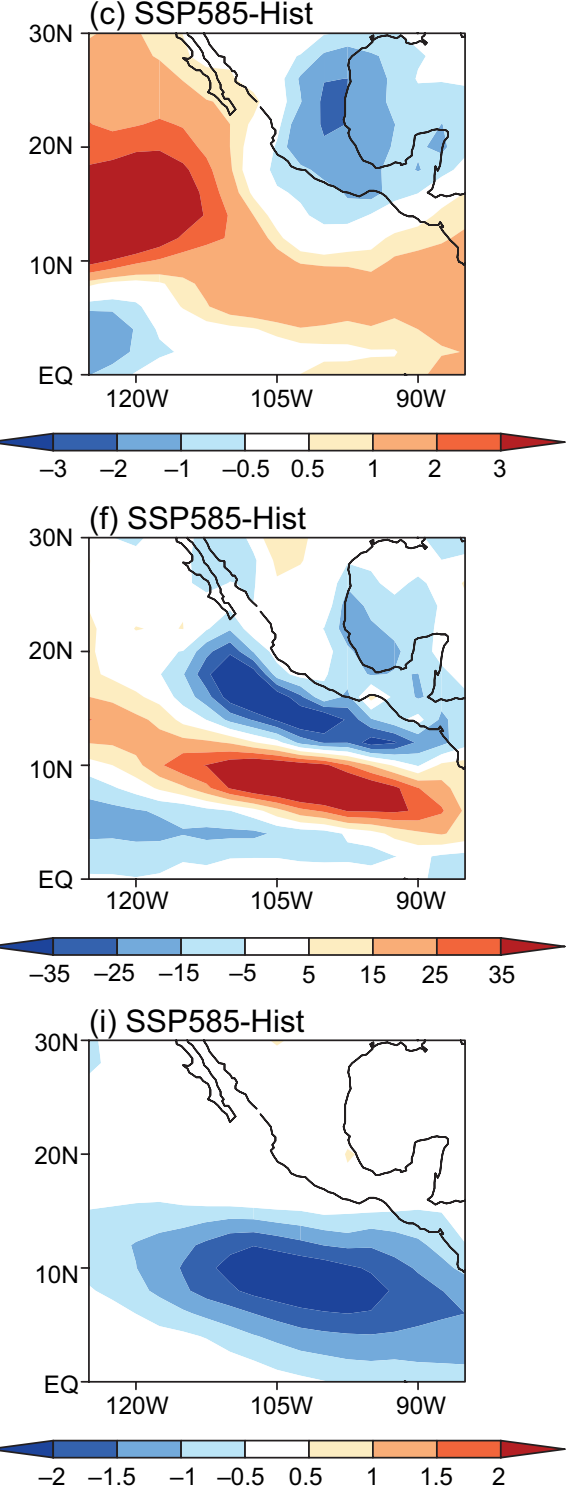

Fig. 7. Similar to Figure 5, but for composite (a-c) $600 \mathrm{hPa}$ relative humidity (\%), (d-f) $850 \mathrm{hPa}$ relative vorticity $\left(10^{7} \mathrm{~s}^{-1}\right)$ and (g-i) magnitude of vertical wind shear between $250 \mathrm{hPa}$ wind and $850 \mathrm{hPa}$ wind $\left(\mathrm{m} \mathrm{s}^{-1}\right)$ from $(\mathrm{a}, \mathrm{d}, \mathrm{g})$ observations, $(\mathrm{b}, \mathrm{e}, \mathrm{h})$ CMIP6 historical simulation multimodel mean and $(\mathrm{c}, \mathrm{f}, \mathrm{i})$ differences between the SSP585 and historical simulations.

shows the composite pattern of the $600 \mathrm{hPa}$ relative humidity from observational analyses, the historical simulation multimodel mean, and the difference in SSP585 relative to the historical. ERA5 relative humidity anomalies peak within ISO convective areas (cf. Fig. 5). The CMIP6 anomalies tend to slightly underestimate the magnitude of relative humidity anomalies that are also more confined to coastal regions, with a prominent negative anomaly to the west of $120^{\circ} \mathrm{W}$ that is weaker in observations (Fig. 7b). Under global warming, the relative humidity anomalies become weaker near the coast and shift westward (Fig. 7c), consistent with the pattern of precipitation anomalies.

The $850 \mathrm{hPa}$ relative vorticity field is characterized by cyclonic anomalies north of the axis of strongest 
wind anomalies, approximately coincident with the area of enhanced precipitation (cf. Figs. $5 \mathrm{a}$ and $7 \mathrm{~d}-\mathrm{e}$ ). A band of anticyclonic vorticity anomalies occurs to the south of the axis of maximum winds, coincident with the narrow band of suppressed convection (between $8^{\circ}$ and $\left.10^{\circ} \mathrm{N}\right)$. Under global warming, vorticity anomalies weaken relative to the current climate (Fig. 7f), consistent with the weakening of the ISO circulation with warming. We also examine the change in composite eastern North Pacific vertical wind shear magnitude between 250 and $850 \mathrm{hPa}$ levels (Fig. 7g-i). The anomalous vertical shear patterns are similar between observations and the CMIP6 multimodel mean with low shear anomalies occurring at the same location as cyclonic anomalies (cf. panels [d-e] and [g-h] in Fig. 7) with the maximum wind shear to the south (equator to $10^{\circ} \mathrm{N}$ ). It is worth noting that the smaller magnitude of wind shear in the CMIP6 relative to ERA5 is because the field is averaged across multiple models that have peak variability in slightly different places, thus resulting in smaller multimodel mean composite amplitude. In a warmer climate, the vertical shear near the Mexico coast shows only modest changes in the region of positive vorticity anomalies (cf. panels [f] and [i] in Fig. 7), with greater reductions in anomalies to the south. In other words, both thermodynamic and dynamic changes suggest less favorable conditions during the convectively enhanced ISO phase for TC genesis in the traditional ENP TC genesis region $\left(10^{\circ}-20^{\circ} \mathrm{N}, 90^{\circ}-120^{\circ} \mathrm{W}\right.$; also see their figure 1 in Maloney and Hartmann, 2000) in a future warmer climate.
Individual models (not shown), as might be expected, produce noisier patterns than the multimodel means, as well as different amplitude responses, although the overall conclusions on the sense of the change are consistent with the multimodel mean.

Based on the above and previous results from Camargo et al. (2009) and Jiang et al. (2012), we might expect that GPI anomalies that favor TC genesis in favored eastern North Pacific regions during the convectively active ISO phase will decrease with global warming. This is demonstrated in Figure 8, which shows the ENP ISO composite of GPI from the multimodel mean of eight CMIP6 models during the boreal summer. The multimodel mean does an excellent job capturing observed GPI variability in the TC genesis region near the Mexico coast, where positive genesis potential anomalies occur (Fig. 8a; also see their figure 1 in Maloney and Hartmann, 2000) in the region of positive precipitation anomalies (cf. Fig. 5). In SSP585, the peak of GPI tends to shift southwest, resulting in a reduction in anomalous GPI near the coast (Fig. 8c), consistent with the change in ENP ISO precipitation and wind anomaly patterns shown in Figure 5, and also the variables that go into GPI including relative humidity, vorticity, and shear shown in Figure 7.

To understand the pattern shift of GPI anomalies, we further decompose these and their changes in a warmer climate into the contributions from each environmental variable: relative humidity, absolute vorticity and magnitude of vertical shear (Fig. 9).

\section{Genesis Potential Index (GPI)}

(a) Hist

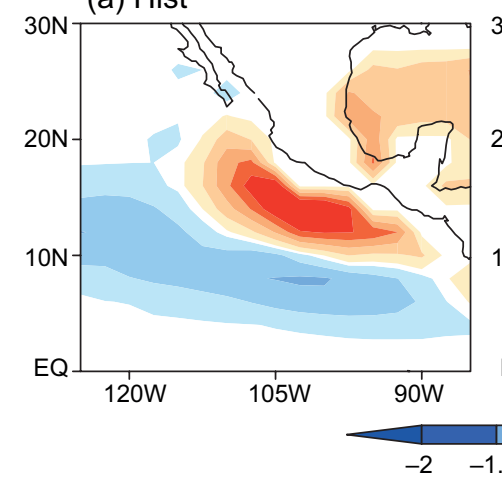

(b) SSP585

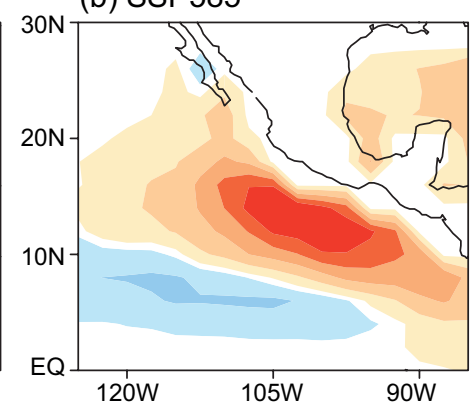

(c) SSP585-Hist

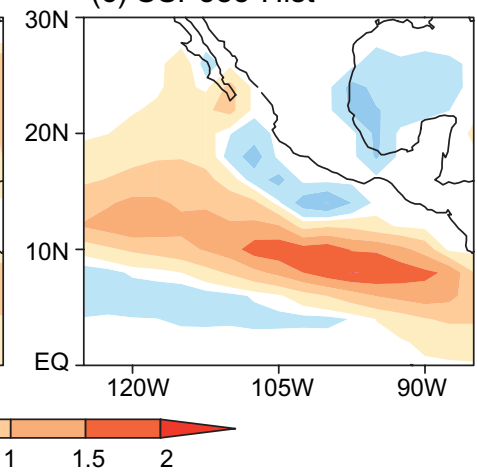

Fig. 8. Boreal summer GPI composite from eight CMIP6 models for (a) historical multimodel mean,

(b) SSP585 multimodel mean, and (c) differences between SSP585 and historical. 
(a) Total $(\mathrm{d}+\mathrm{g}+\mathrm{j})$
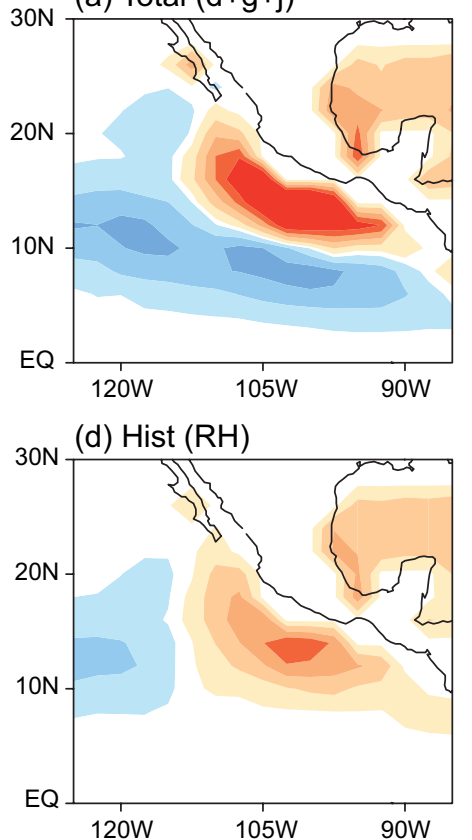

(d) Hist (Vor)

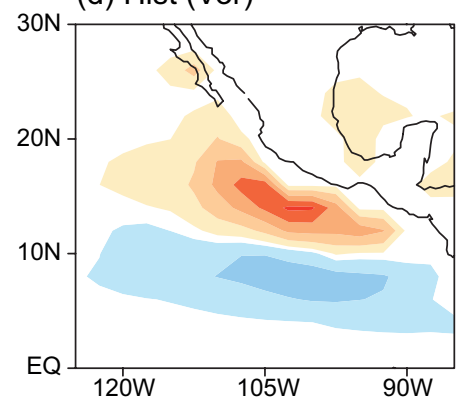

(j) Hist (Shear)

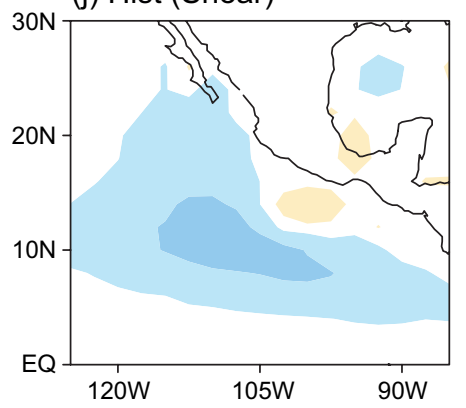

(b) Total $(e+h+k)$

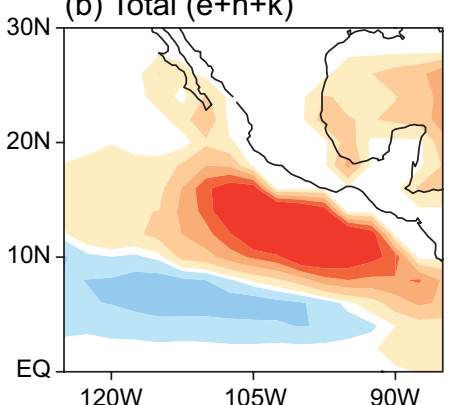

(e) SSP585(RH)

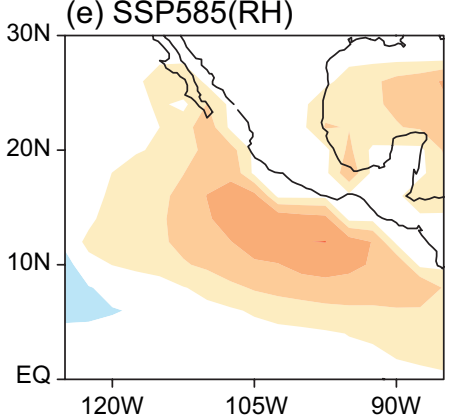

(e) SSP585(Vor)

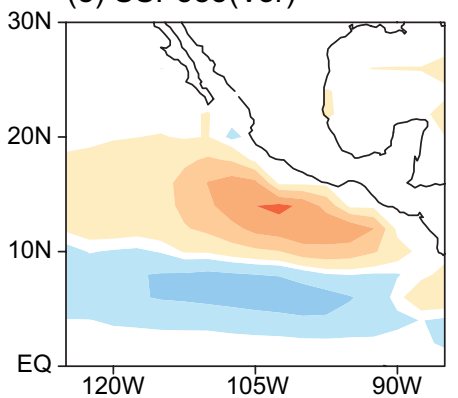

(e) SSP585(Shear)

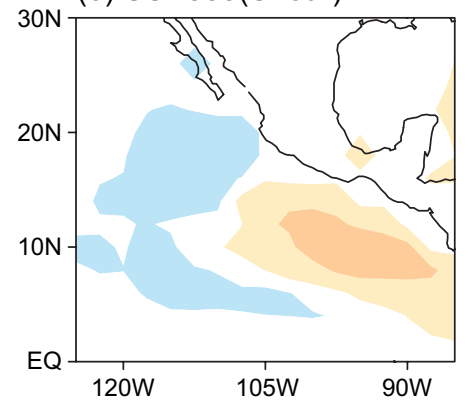

(c) Total $(\mathrm{f}+\mathrm{i}+\mathrm{l})$
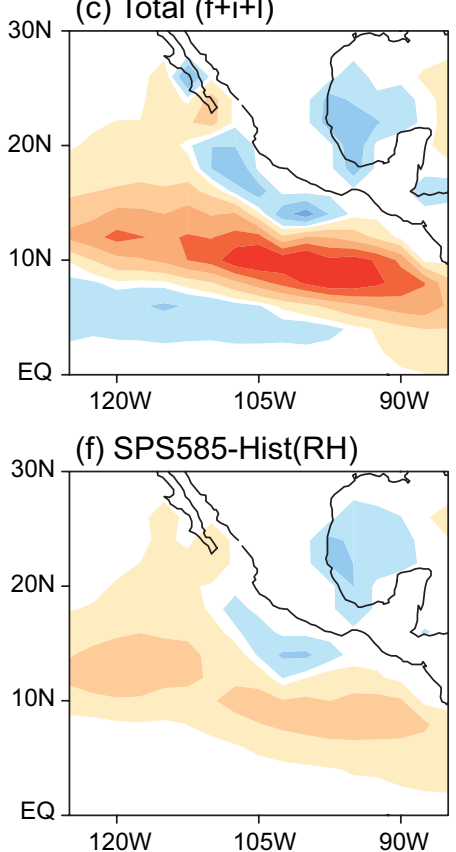

(f) SPS585-Hist(Vor)

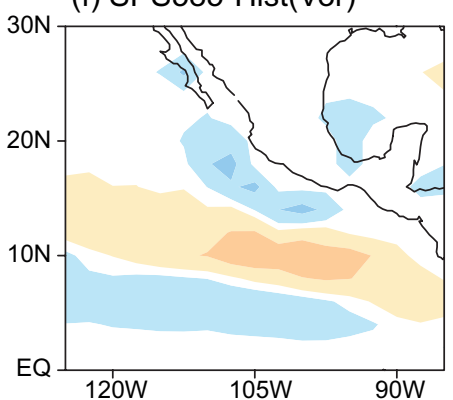

(f) SPS585-Hist(Shear)

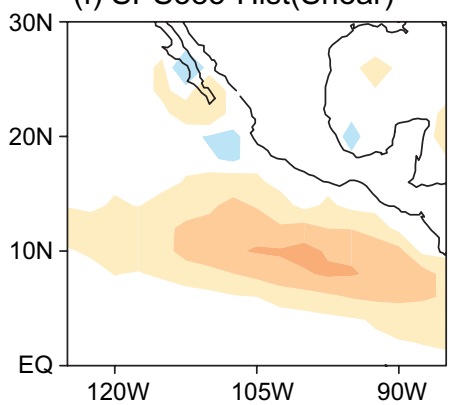

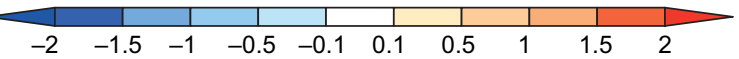

Fig. 9. Same as Figure 8, except for the contributions of the three main environmental variables (d-f) $600 \mathrm{hPa}$ relative humidity, (g-i) $850 \mathrm{hPa}$ absolute vorticity, and (j-1) magnitude of vertical wind shear between $250 \mathrm{hPa}$ and $850 \mathrm{hPa}$ to the GPI anomalies (shown in Fig. 8). The first row shows the result of adding the three components. 
As mentioned before, to conduct this calculation we allow two variables to vary while the third one is fixed to the corresponding annual cycle. The result of adding the three contributions calculated this way produces a similar anomaly pattern to the total field shown in Figure 8 (cf. Figs. 9a-c and 8), with a reduction of GPI anomalies near the coast with warming, and strengthening to the southwest. Both relative humidity and vorticity changes with warming are associated to the weakening GPI anomalies near the coast with warming and increase of GPI anomalies to the southwest (Fig. 9), consistent with the respective fields shown in Figure 7. The vorticity changes are also consistent with the reduction of ISO wind amplitude previously discussed. The effect of shear anomalies on GPI has a larger contribution than humidity and vorticity in increasing GPI anomalies away from the coast. The result generally highlights the importance of both dynamical and thermodynamic factors to the reduction of positive GPI anomalies during the enhanced ISO phase near the coastal region under global warming and suggests that the ISO will favor TC genesis over the region away from the coast in a future warmer climate.

\section{Conclusions}

We have analyzed the historical and SSP585 simulations from 14 CMIP6 models to understand the change of boreal summer intraseasonal variability over the eastern north Pacific (ENP) with climate warming and its influence on tropical cyclone (TC) genesis. We specifically analyzed a genesis potential index (GPI) and its components to understand how individual genesis potential variables influence changes in GPI anomalies during ISO events with climate warming. Our primary conclusions are as follows:

In the ENP under global warming in SSP585, the CMIP6 multimodel mean shows decreases in intraseasonal precipitation and low-level westerly wind anomaly amplitude in regions near the Mexican coast (Figs. 2 and 5), although wind amplitude decreases are stronger (Fig. 6). The stronger decreases in ISO wind amplitude are consistent with those found in previous studies of the MJO in the Indo-Pacific region (Maloney et al., 2019).

The amplitude maximum for ENP intraseasonal precipitation and wind anomalies during enhanced
ISO precipitation events also tends to shift southwestward in a warmer climate (Fig. 5c).

Positive ISO precipitation events are associated with weaker intraseasonal GPI anomalies near the Mexican coast with warming, and an enhancement of positive GPI anomalies to the southwest. A decomposition of the GPI anomalies into thermodynamic (i.e., relative humidity) and dynamic (vorticity and vertical shear) components was conducted to assess the importance of these factors for regulating GPI anomaly changes with warming. Relative humidity and vorticity changes during ISO events weaken positive GPI anomalies near the Mexican coast with warming and make genesis more favorable to the southwest. The impact of vertical shear anomaly changes is to favor genesis away from the coast.

The results here suggest that weakening of ENP ISO wind anomalies and a general southwestward shift of the ISO maxima in a future warmer climate would importantly impact TC activity in this region. In particular, TC genesis is projected to be less favored near the coast during ISO events and more favored to the southwest. The current study only focuses on the ISO timescale over the ENP, thus extending this analysis to examine other types of climate variability (such as with the ENSO) would be warranted. Although we found generally consistent results among models in ISO amplitude and pattern changes with warming, projected future changes still vary considerably in their details among the models (e.g., Fig. 6). Therefore, a larger ensemble of climate model simulations would help assess the robustness of our analysis. Recent studies (e.g., Sobel et al., 2019) show that aerosol cooling reduces TC potential intensity more strongly than greenhouse gases warming increase it. A more in-depth study with climate model simulations that can separate external forcing into its various components (e.g., greenhouse gases, aerosols) and natural variability (e.g., decadal variability) would be useful to clarify the impact of each forcing agent on the ISO and the regional TC activity.

\section{Acknowledgments}

This work was supported by the Climate and LargeScale Dynamics Program of the National Science Foundation under grants AGS-1735978 and AGS-1841754. 
We thank the World Climate Research Programme (WCRP) Working Group for providing the CMIP6 data, which can be downloaded at https://esgf-node. 1lnl.gov/search/cmip6/. The ERA5 data and NOAA outgoing longwave radiation data were obtained from the NCAR Research Data Archive (https:// doi.org/10.5065/BH6N-5N20) and NOAA Physical Sciences Laboratory (https://psl.noaa.gov/data/ gridded/data.interp_OLR.html), respectively. We also thank the NASA Goddard Space Flight Center for providing the global precipitation measurement (GPM) precipitation (https://gpm.nasa.gov/data-access/downloads/gpm). A Python code to calculate the potential intensity is available online (https:// emanuel.mit.edu/products).

\section{References}

Adames ÁF, Kim D, Sobel AH, Del Genio A, Wu J. 2017a. Changes in the structure and propagation of the MJO with increasing CO2. Journal of Advances in Modeling Earth Systems 9: 1251-1268. https://doi. org/10.1002/2017MS000913

Adames ÁF, Kim D, Sobel AH, Del Genio A, Wu J. 2017b. Characterization of moist processes associated with changes in the propagation of the MJO with increasing CO2. Journal of Advances in Modeling Earth Systems 9: 2946-2967. https://doi.org/10.1002/2017MS001040

Aiyyer A, Molinari J. 2008. MJO and tropical cyclogenesis in the Gulf of Mexico and eastern Pacific: Case study and idealized numerical modeling. Journal of the Atmospheric Sciences 65: 2691-2704. https://doi. org/10.1175/2007JAS2348.1

Arnold NP, Kuang Z, Tziperman E. 2013. Enhanced MJOlike variability at high SST. Journal of Climate 26: 988-1001. https://doi.org/10.1175/JCLI-D-12-00272.1

Arnold NP, Branson M, Kuang Z, Randall DA, Tziperman E. 2015. MJO intensification with warming in the superparameterized CESM. Journal of Climate 28: 27062724. https://doi.org/10.1175/JCLI-D-14-00494.1

Barrett BS, Leslie LM. 2009. Links between tropical cyclone activity and Madden-Julian oscillation phase in the north Atlantic and northeast Pacific basins. Monthly Weather Review 137: 727-744. https://doi. org/10.1175/2008MWR2602.1

Bister M, Emanuel KA. 1998. Dissipative heating and hurricane intensity. Meteorology and Atmospheric Physics 65: 233-240. https://doi.org/10.1007/BF01030791
Bui HX, Maloney ED. 2018. Changes in Madden-Julian oscillation precipitation and wind variance under global warming. Geophysical Research Letters 45: 7148-7155. https://doi.org/10.1029/2018GL078504

Bui HX, Maloney ED. 2019a. Mechanisms for global warming impacts on Madden-Julian Oscillation precipitation amplitude. Journal of Climate 32: 6961-6975. https://doi.org/10.1175/JCLI-D-19-0051.1

Bui HX, Maloney ED. 2019b. Transient response of MJO precipitation and circulation to greenhouse gas forcing. Geophysical Research Letters 46: 13546-13555. https://doi.org/10.1029/2019GL085328

Bui HX, Maloney ED. 2020. Changes to the Madden-Julian oscillation in coupled and uncoupled aquaplanet simulations with $4 \times \mathrm{xCO} 2$. Journal of Advances in Modeling Earth Systems 12: e2020MS002179. https://doi. org/10.1029/2020MS002179

Camargo SJ, Emanuel KA, Sobel AH. 2007. Use of a genesis potential index to diagnose ENSO effects on tropical cyclone genesis. Journal of Climate 20: 48194834. https://doi.org/10.1175/JCLI4282.1

Camargo SJ, Robertson AW, Barnston AG, Ghil M. 2008. Clustering of eastern north Pacific tropical cyclone tracks: ENSO and MJO effects. Geochemistry Geophysics Geosystems 9: Q06V05. https://doi. org/10.1029/2007GC001861

Camargo SJ, Wheeler MC, Sobel AH. 2009. Diagnosis of the MJO modulation of tropical cyclogenesis using an empirical index. Journal of the Atmospheric Sciences 66: 3061-3074. https://doi.org/10.1175/ 2009JAS3101.1

Chang CWJ, Tseng WL, Hsu HH, Keenlyside N, Tsuang BJ. 2015. The Madden-Julian oscillation in a warmer world. Geophysical Research Letters 42: 6034-6042. https://doi.org/10.1002/2015GL065095

Chou C, Neelin JD, Chen CA, Tu JY. 2009. Evaluating the "Rich-Get-Richer" mechanism in tropical precipitation change under global warming. Journal of Climate 22: 1982-2005. https://doi.org/10.1175/2008JCLI2471.1

Domínguez C, Magaña V. 2018. The role of tropical cyclones in precipitation over the tropical and subtropical North America. Frontiers in Earth Science 6: 19. https://doi.org/10.3389/feart.2018.00019

Emanuel KA. 1995. Sensitivity of tropical cyclones to surface exchange coefficients and a revised steady-state model incorporating eye dynamics. Journal of the Atmospheric Sciences 52: 3969-3976. https://doi.org/10. 1175/1520-0469(1995)052<3969:SOTCTS $>2.0 . C O ; 2$ 
Emanuel KA, Nolan DS. 2004. Tropical cyclone activity and global climate. 26th Conference on Hurricanes and Tropical Meteorology, Miami, FL. American Meteorological Society, 240-241.

Englehart PJ, Douglas AV. 2001. The role of eastern North Pacific tropical storms in the rainfall climatology of western Mexico. International Journal of Climatology 21: 1357-1370. https://doi.org/10.1002/joc.637

Eyring V, Bony S, Meehl GA, Senior CA, Stevens B, Stouffer RJ, Taylor KE. 2016. Overview of the coupled model intercomparison project phase 6 (CMIP6) experimental design and organization. Geoscientific Model Development 9: 1937-1958. https://doi.org/10.5194/ gmd-9-1937-2016

Hall JD, Matthews AJ, Karoly DJ. 2001. The modulation of tropical cyclone activity in the Australian region by the Madden-Julian oscillation. Monthly Weather Review 129: 2970-2982. https://doi. org/10.1175/1520-0493(2001)129<2970:TMOT$\mathrm{CA}>2.0 . \mathrm{CO} ; 2$

Hersbach H, Bell B, Berrisford P, Hirahara S, Horányi A, Muñoz-Sabater J , Nicolas J, Peubey C, Radu R, Schepers D, Simmons A, Soci C, Abdalla S, Abellan X, Balsamo G, Bechtold P, Biavati G, Bidlot J, Bonavita M, De Chiara G, Dahlgren P, Dee D, Diamantakis M, Dragani R, Flemming J, Forbes R, Fuentes M, Geer A, Haimberger L, Healy S, Hogan RJ, Hólm E, Janisková M, Keeley S, Laloyaux P, Lopez P, Lupu C, Radnoti G, de Rosnay P, Rozum I, Vamborg F, Villaume S, Thépaut JN. 2020. The ERA5 global reanalysis. Quarterly Journal of the Royal Meteorological Society 146: 1999-2049. https://doi. org/10.1002/qj.3803

Higgins RW, Shi W. 2005. Relationships between Gulf of California moisture surges and tropical cyclones in the eastern Pacific basin. Journal of Climate 18: 46014620. https://doi.org/10.1175/JCLI3551.1

Huffman GJ, Bolvin DT, Braithwaite D, Hsu K, Joyce R, Kidd C, Nelkin EJ, Xie P. 2018. NASA global precipitation measurement (GPM) integrated multi-satellite retrievals for GPM (IMERG). Algorithm theoretical basis document (ATBD), version 4.5, $26 \mathrm{pp}$.

Jiang X, Waliser DE. 2008. Northward propagation of the subseasonal variability over the eastern Pacific warm pool. Geophysical Research Letters 35: L09814. https://doi.org/10.1029/2008GL033723

Jiang X, Waliser DE. 2009. Two dominant subseasonal variability modes of the eastern Pacific ITCZ.
Geophysical Research Letters 36: L04704. https://doi. org/10.1029/2008GL036820

Jiang X, Zhao M, Waliser DE. 2012. Modulation of tropical cyclones over the eastern Pacific by the intraseasonal variability simulated in an AGCM. Journal of Climate 25: 6524-6538. https://doi.org/10.1175/ JCLI-D-11-00531.1

Jiang X, Maloney ED, Li JLF, Waliser DE. 2013. Simulations of the eastern north Pacific intraseasonal variability in CMIP5 GCMs. Journal of Climate 26: 3489-3510. https://doi.org/10.1175/JCLI-D-12-00526.1

Klotzbach PJ. 2010. On the Madden-Julian oscillation-Atlantic hurricane relationship. Journal of Climate 23: 282-293. https://doi.org/10.1175/2009JCLI2978.1

Klotzbach PJ. 2014. The Madden-Julian oscillation's impacts on worldwide tropical cyclone activity. Journal of Climate 27: 2317-2330. https://doi.org/10.1175/ JCLI-D-13-00483.1

Knutson T, McBride JL, Chan J, Emanuel K, Holland G, Landsea C, Held I, Kossin JP, Srivastava AK, Sugi M. 2010. Tropical cyclones and climate change. Nature Geoscience 3: 157-163. https://doi.org/10.1038/ ngeo779

Knutson T, Camargo SJ, Chan J, Emanuel K, Ho C-H, Kossin J, Mohapatra M, Satoh M, Sugi M, Walsh K, Wu L. 2020. Tropical cyclones and climate change assessment: Part II: Projected response to anthropogenic warming. Bulletin of the American Meteorological Society 101: E303-E322. https://doi.org/10.1175/ BAMS-D-18-0194.1

Lee JY, Wang B, Wheeler MC, Fu X, Waliser DE, Kang IS. 2013. Real-time multivariate indices for the boreal summer intraseasonal oscillation over the Asian summer monsoon region. Climate Dynamics 40: 493-509. https://doi.org/10.1007/s00382-012-1544-4.

Liebmann B, Hendon HH, Glick JD. 1994. The relationship between tropical cyclones of the western Pacific and Indian Oceans and the Madden-Julian oscillation. Journal of the Meteorological Society of Japan 72: 401-412. https://doi.org/10.2151/jmsj1965.72.3_401

Liebmann B, Smith CA. 1996. Description of a complete (interpolated) outgoing longwave radiation dataset. Bulletin of the American Meteorological Society 77: 1275-1277.

Lin J, Mapes BE, Weickmann KM, Kiladis GN, Schubert SD, Suarez MJ, Bacmeister JT, Lee MI. 2008. North American monsoon and convectively coupled equatorial waves simulated by IPCC AR4 coupled 
GCMs. Journal of Climate 21: 2919-2937. https://doi. org/10.1175/2007JCLI1815.1

Madden RA, Julian PR. 1971. Detection of a 40-50-day oscillation in the zonal wind in the tropical Pacific. Journal of the Atmospheric Sciences 28: 702-708. https://doi.org/10.1175/1520-0469(1971)028<0702:DOADOI $>2.0 . \mathrm{CO} ; 2$

Madden RA, Julian PR. 1972. Description of global-scale circulation cells in the Tropics with a 40-50-day period Journal of the Atmospheric Sciences 29: 1109-1123. https://doi.org/10.1175/1520-0469(1972)029<1109:D OGSCC $>2.0 . \mathrm{CO} ; 2$

Maloney ED, Hartmann DL. 2000. Modulation of hurricane activity in the Gulf of Mexico by the Madden-Julian oscillation. Science 287: 2002-2004. https://doi. org/10.1126/science.287.5460.2002

Maloney ED, Hartmann DL. 2001. The Madden-Julian oscillation, barotropic dynamics, and north Pacific tropical cyclone formation. Part I: Observations. Journal of the Atmospheric Sciences 58: 2545-2558. https://doi.org/10.1175/1520-0469(2001)058<2545:TMJOBD $>2.0 . \mathrm{CO} ; 2$

Maloney ED, Esbensen SK. 2003. The amplification of east Pacific Madden-Julian oscillation convection and wind anomalies during June-November. Journal of Climate 16: 3482-3497. https://doi.org/10.1175/1520 $-0442(2003) 016<3482:$ TAOEPM $>2.0 . \mathrm{CO} ; 2$

Maloney ED, Esbensen SK. 2005. A modeling study of summertime east Pacific wind-induced ocean-atmosphere exchange in the intraseasonal oscillation. Journal of Climate 18: 568-584. https://doi.org/10.1175/ JCLI-3280.1

Maloney ED, Esbensen SK. 2007. Satellite and buoy observations of boreal summer intraseasonal variability in the tropical northeast Pacific. Monthly Weather Review 135: 3-19. https://doi.org/10.1175/MWR3271.1

Maloney ED, Chelton DB, Esbensen SK. 2008. Subseasonal SST variability in the tropical eastern north Pacific during boreal summer. Journal of Climate 21: 4149-4167. https://doi.org/10.1175/2007JCLI1856.1

Maloney ED, Jiang X, Xie SP, Benedict JJ. 2014. Process-oriented diagnosis of east Pacific warm pool intraseasonal variability. Journal of Climate 27: 6305-6324. https://doi.org/10.1175/JCLI-D-14-00053.1

Maloney ED, Adames ÁF, Bui HX. 2019. Madden-Julian oscillation changes under anthropogenic warming. Nature Climate Change 9: 26-33. https://doi.org/10.1038/ s41558-018-0331-6
Misra V, Groenen D, Bhardwaj A, Mishra A. 2016. The warm pool variability of the tropical northeast Pacific. International Journal of Climatology 36: 4625-4637. https://doi.org/10.1002/joc.4658

Molinari J, Knight D, Dickinson M, Vollaro D, Skubis S. 1997. Potential vorticity, easterly waves, and eastern Pacific tropical cyclogenesis. Monthly Weather Review 125: 2699-2708. https://doi.org/10.1175/1520-0493(1 997)125<2699:PVEWAE $>2.0 . C O ; 2$

Murakami H, Delworth TL, Cooke WF, Zhao M, Xiang B, Hsu PC. 2020. Detected climatic change in global distribution of tropical cyclones. Proceedings of the National Academy of Sciences 117: 10706. https:// doi.org/10.1073/pnas.1922500117

Neelin JD, Münnich M, Su H, Meyerson JE, Holloway CE. 2006. Tropical drying trends in global warming models and observations. Proceedings of the National Academy of Sciences 103: 6110-6115. https://doi. org/10.1073/pnas.0601798103

Neena JM, Jiang X, Waliser D, Lee JY, Wang B. 2014. Eastern Pacific intraseasonal variability: A predictability perspective. Journal of Climate 27: 8869-8883. https://doi.org/10.1175/JCLI-D-14-00336.1

O’Neill BC, Tebaldi C, van Vuuren DP, Eyring V, Friedlingstein P, Hurtt G, Knutti R, Kriegler E, Lamarque JF, Lowe J, Meehl GA, Moss R, Riahi K, Sanderson BM. 2016. The scenario model intercomparison project (ScenarioMIP) for CMIP6. Geoscientific Model Development 9: 3461-3482. https://doi.org/10.5194/gmd-9-3461-2016

Ritchie EA, Wood KM, Gutzler DS, White SR. 2011. The influence of eastern Pacific tropical cyclone remnants on the southwestern United States. Monthly Weather Review 139: 192-210. https://doi.org/10.1175/2010MWR3389.1

Romero-Vadillo E, Zaytsev O, Morales-Pérez R. 2007. Tropical cyclone statistics in the northeastern Pacific. Atmósfera 20: 197-213.

Rushley SS, Kim D, Adames ÁF. 2019. Changes in the MJO under greenhouse gas-induced warming in CMIP5 models. Journal of Climate 32: 803-821. https://doi.org/10.1175/JCLI-D-18-0437.1

Rydbeck AV, Maloney ED, Xie S, Hafner J, Shaman J. 2013. Remote forcing versus local feedback of east Pacific intraseasonal variability during boreal summer. Journal of Climate 26: 3575-3596. https://doi. org/10.1175/JCLI-D-12-00499.1

Slade SA, Maloney ED. 2013. An intraseasonal prediction model of Atlantic and east Pacific tropical cyclone 
genesis. Monthly Weather Review 141: 1925-1942. https://oi.org/10.1175/MWR-D-12-00268.1

Sobel AH, Camargo SJ, Previdi M. 2019. Aerosol vs. greenhouse gas effects on tropical cyclone potential intensity and the hydrologic cycle. Journal of Climate 32: 5511-5527. https://doi.org/10.1175/ JCLI-D-18-0357.1

Takahashi C, Sato N, Seiki A, Yoneyama K, Shirooka R. 2011. Projected future change of MJO and its extratropical teleconnection in East Asia during the northern winter simulated in IPCC AR4 models. Science Online Letters on the Atmosphere 7: 201-204. https://doi. org/10.2151/sola.2011-051

Wang C, Enfield DB. 2001. The tropical western hemisphere warm pool. Geophysical Research Letters 28: 1635-1638, https://doi.org/10.1029/2000GL011763
Wheeler M, Hendon HH. 2004. An all-season real-time multivariate MJO index: Development of an index for monitoring and prediction. Monthly Weather Review 132: 1917-1932. https://doi.org/10.1175/1520-0493(2 004) $132<1917$ :AARMMI $>2.0 . \mathrm{CO} ; 2$

Xie SP, Xu H, Kessler WS, Nonaka M. 2005. Air-sea interaction over the eastern Pacific warm pool: Gap winds, thermocline dome, and atmospheric convection. Journal of Climate 18: 5-20. https://doi.org/10.1175/ JCLI-3249.1

Yeh S., Kug JS, Dewitte B, Kwon MH, Kirtman BP, Jin FF. 2009. El Niño in a changing climate. Nature 461: 511-514. https://doi.org/10.1038/nature08316

Zhao C, Li T. 2019. Basin dependence of the MJO modulating tropical cyclone genesis. Climate Dynamics 52: 6081-6096. https://doi.org/10.1007/s00382-018-4502-y 


\section{Supplementary Material}
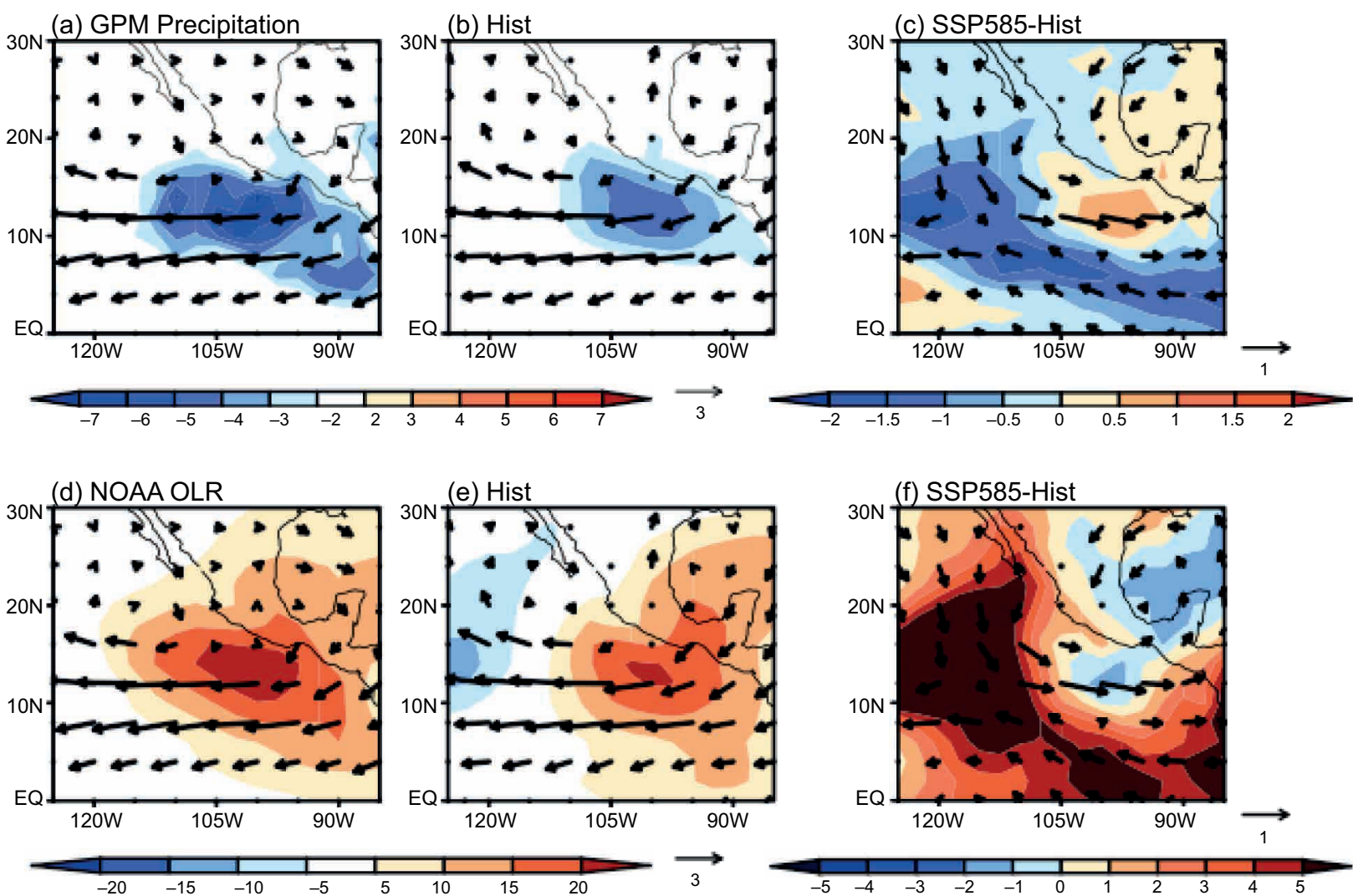

Fig. S1. Similar to Figure 5, but for composite based on negative deviation of the PC1.

(a) Precipitation (Hist)
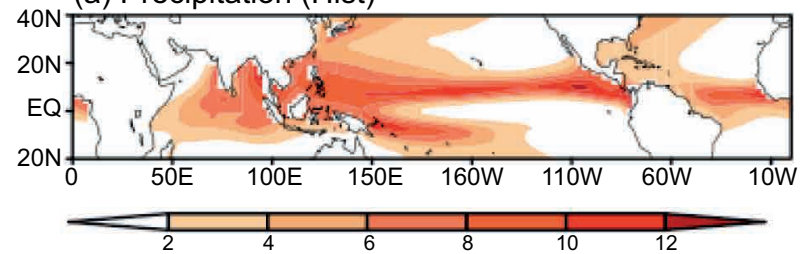

(c) OLR (Hist)
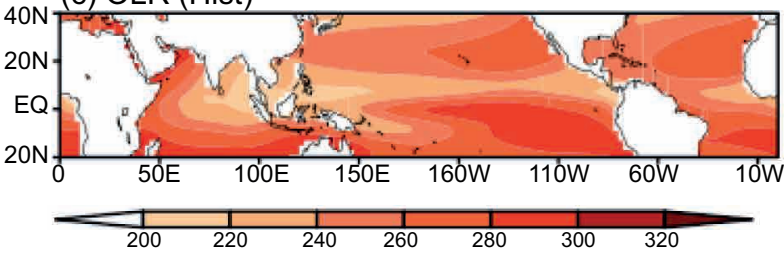

(e) 4850 (Hist)

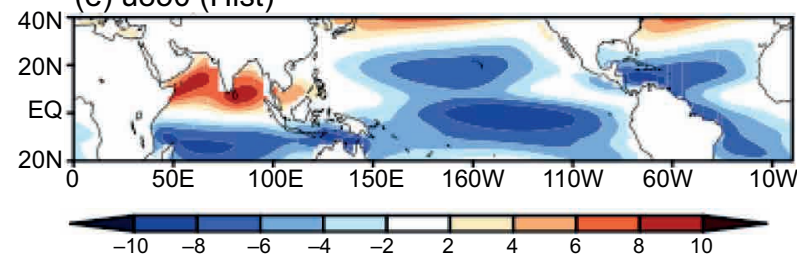

Fig. S2. Same as Figure 1, but for the entire tropics. (b) Precipitation (SSP585-Hist)

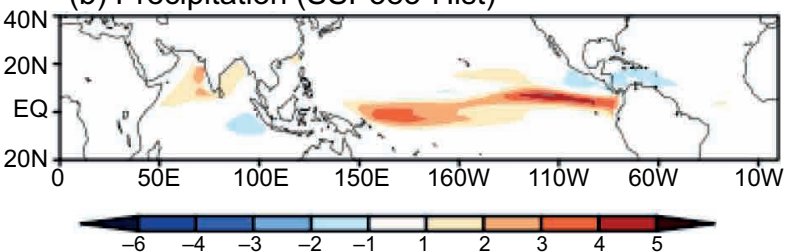

(b) OLR (SSP585-Hist)

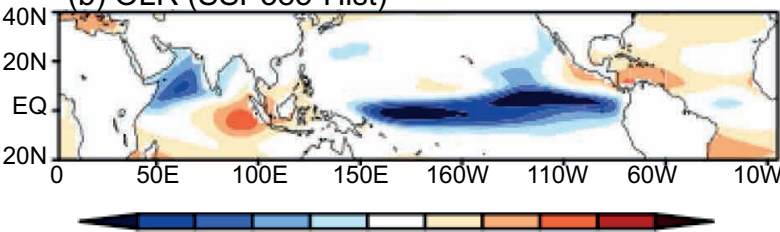

(f) 4850 (SSP585-Hist)

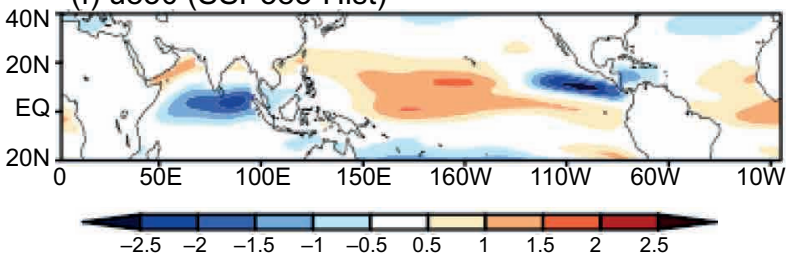


(a) Precipitation (Hist)

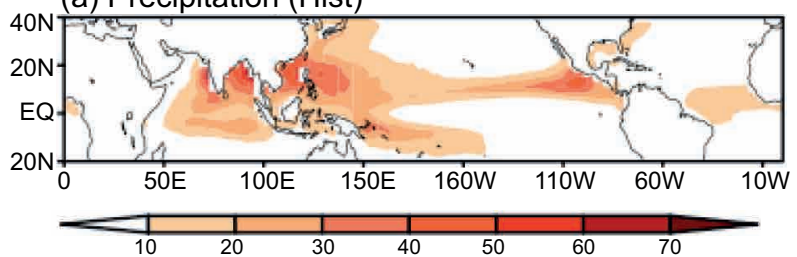

(c) OLR (Hist)

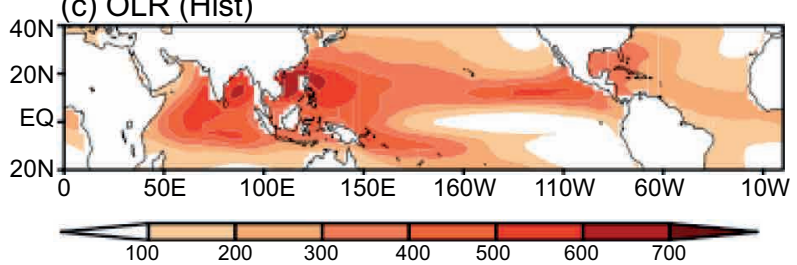

(e) $u 850$ (Hist)

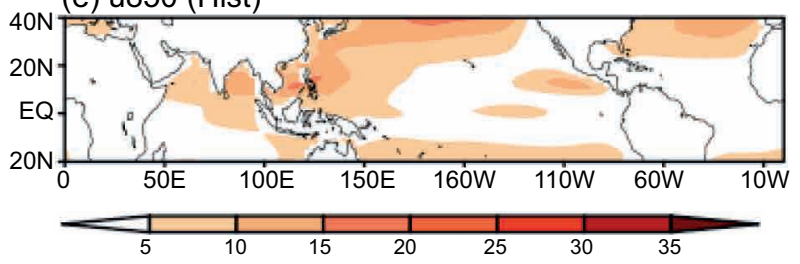

Fig. S3. Same as Figure 2, but for the entire tropics. (b) Hist

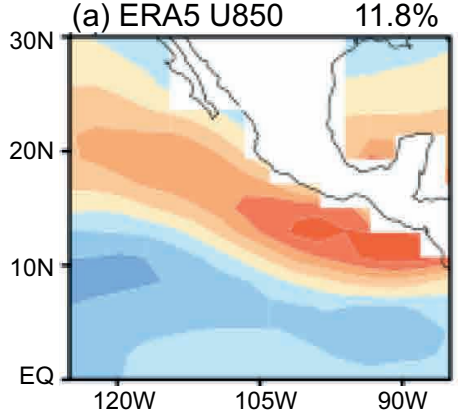

$8.5 \%$
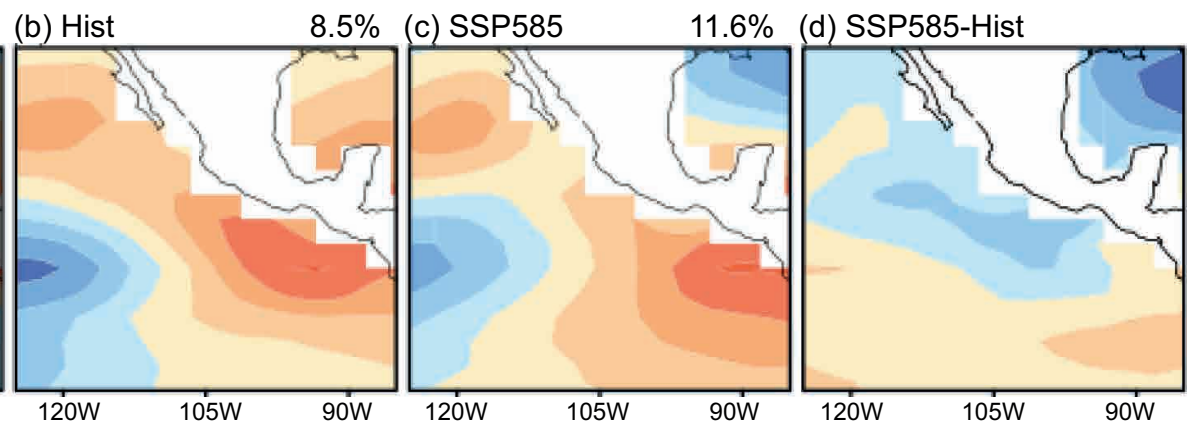

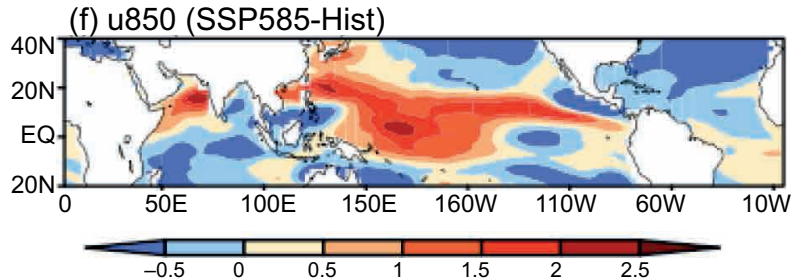

(b) Precipitation (SSP585-Hist)

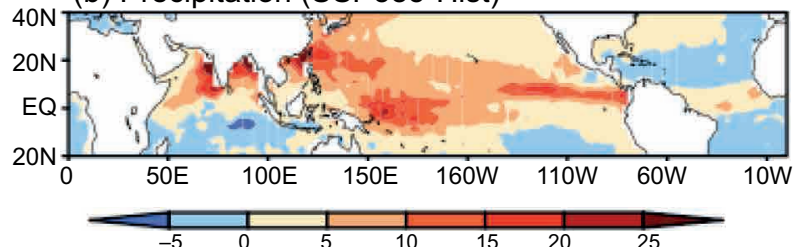

(b) OLR (SSP585-Hist)

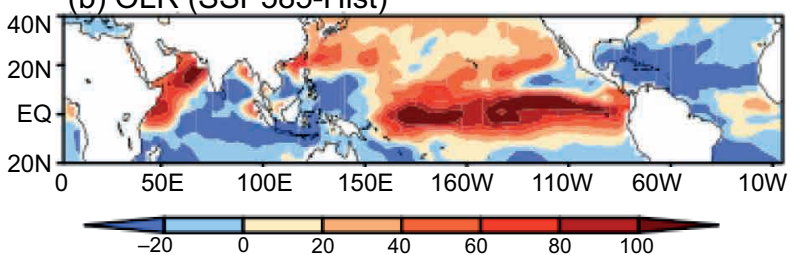

(f) 4850 (SSP585-Hist)
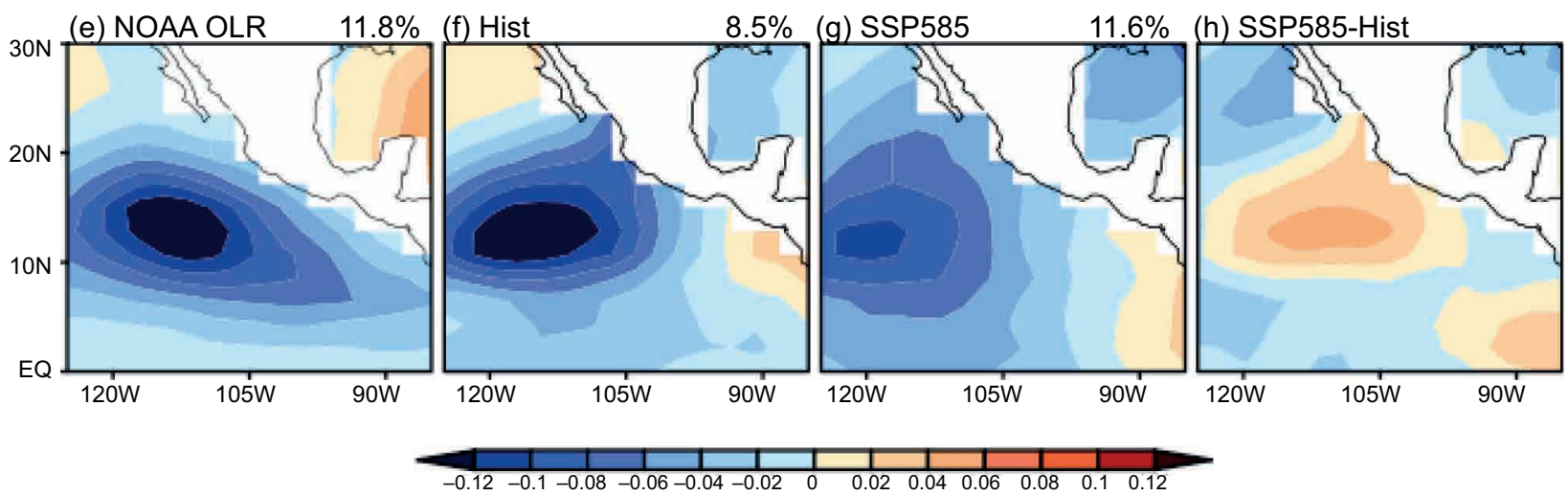

Fig. S4. Same as Figure 3, but for the second CEOF. 


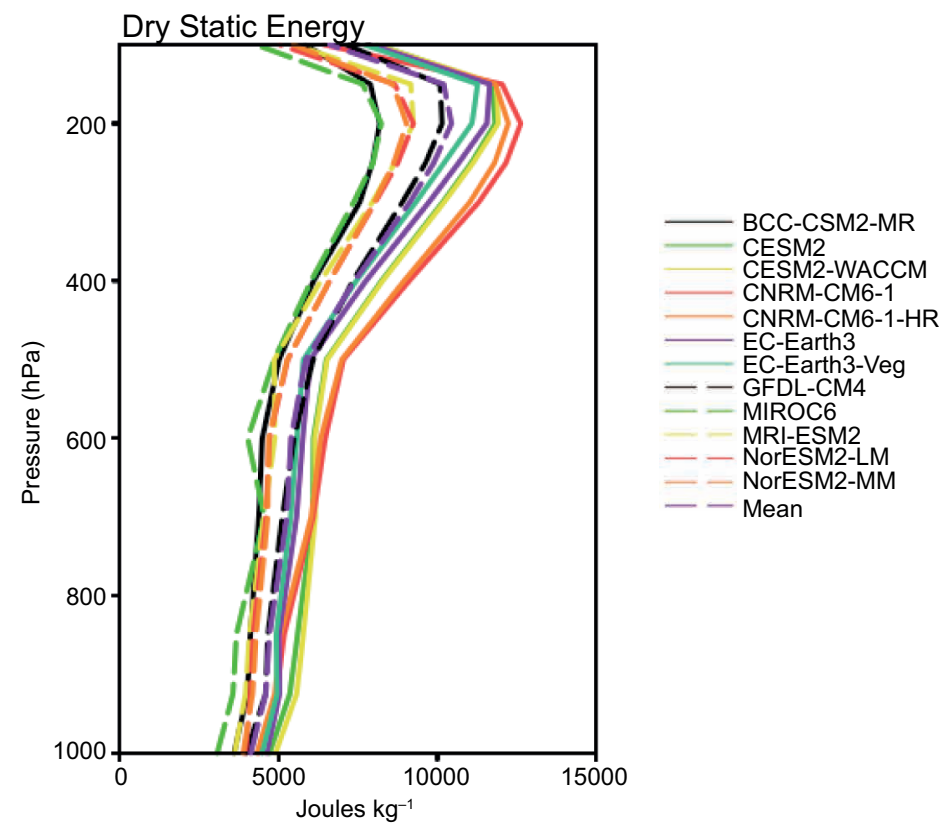

Fig. S5. Changes in vertical structure of May-October mean dry static energy in the SSP585 relative to historical simulations averaged over the eastern North Pacific domain $\left(0-30^{\circ} \mathrm{N}, 85^{\circ}-125^{\circ} \mathrm{W}\right)$. Units are in $\mathrm{J} \mathrm{kg}^{-1}$. 